\title{
The Role of
}

Paraprofessionals in Technical Services in Academic Libraries

\author{
Lihong Zhu
}

Technological advances, budget cuts, reorganizations, downsizing, outsourcing, expanded roles of professionals, and changes in the information world are redistributing the workload between professionals and paraprofessionals in academic library technical services units. Today, paraprofessionals manage major functional areas in technical services and dominate the technical services work force. The roles of paraprofessionals have expanded to include duties once considered the sole responsibilities of professionals in technical services. In 2011, the author conducted a survey to understand more about the roles of technical services paraprofessionals in academic libraries during the previous five years. This paper analyzes the survey results and provides insight into the roles of paraprofessionals in technical services in academic libraries by examining required educational degrees and high-level skills for paraprofessional positions, complex duties that are regularly assigned to paraprofessional positions, and staff development incentives and opportunities.

Lihong Zhu (Izhu2@wsu.edu) is Head of Technical Services, Washington State University Libraries, Pullman, Washington.

Submitted November 3, 2011; tentatively accepted, pending revision, December 14, 2011; revision submitted January 6,2012 , and accepted for publication February 3, 2012.
A ccording to the Online Dictionary for Library and Information Science A (ODLIS), a library paraprofessional is

a member of the library support staff, usually someone who holds at least the baccalaureate degree, trained to understand specific procedures and apply them according to pre-established rules under normal circumstances without exercising professional judgment. Library paraprofessionals are usually assigned high-level technical support duties, for example, in copy cataloging and serials control. In smaller public library systems in the United States, branch librarians are sometimes paraprofessionals. $^{1}$

What to call the group of "library paraprofessionals" has been perplexing and controversial in the past. A brief review of the literature shows that the library profession has reached no consensus. In the past, this group has been called paraprofessionals, library assistants, library specialists, library associates, non-master of library and information science (MLIS) staff, paralibrarians, subprofessionals, nonprofessionals, library aids, library technicians, library support staff, and so on. In this paper, the author chose to use paraprofessionals for the sole purpose 
of consistency. In 2011, the author conducted a survey to understand more about the roles of paraprofessionals in technical services in academic libraries during the previous five years. This paper analyzes the survey results and provides an insight into the roles of technical services paraprofessionals in academic libraries during the previous five years, detailing the required educational degrees and highlevel skills for paraprofessional positions, complex duties that are regularly assigned to paraprofessional positions, and staff development incentives and opportunities.

The questionnaire in the survey was designed to answer the following research questions:

- In the previous five years, what educational degrees and high-level skills have been required for the positions of professionals and paraprofessionals according to their official job descriptions? What are the similarities and differences?

- In the previous five years, what complex duties have been regularly assigned (i.e., officially part of the job description) to professionals and paraprofessionals in academic library technical services units, either full or part time? What are the similarities and differences?

- In the previous five years, have the roles of paraprofessionals in academic library technical services units expanded, grown smaller, or remained the same in complex duties?

- In the previous five years, what incentives do academic libraries offer to paraprofessionals in technical services for staff development?

\section{Literature Review}

As Oberg observed in 1995, "Over the past twenty or more years, automation of library processes, declining budgets, contraction of higher education generally, and entry into the electronic information age have changed libraries. New library tasks have been created and others realigned. This redistribution of the library workload has given rise to a new category of employee, the paraprofessional." ${ }^{2}$ The library literature gives evidence of a lengthy dialogue about paraprofessionals in technical services, often tied to a discussion about professional librarians. ${ }^{3}$ As Oberg noted, "Staff utilization, role definition and articulation, task overlap, educational requirements, certification, and status have been cantankerous issues within the library profession for most of this century and remain largely unresolved today." Although an abundance of publications addressed issues related to paraprofessionals in technical services, many focused exclusively on paraprofessionals in cataloging. This paper will focus on the roles of paraprofessionals in various technical services functions in academic libraries in recent years.

As early as 1923, Williamson challenged the library profession to distinguish unambiguously between professional and paraprofessional duties. ${ }^{5}$ Since 1927, the American Library Association (ALA) has made a series of efforts to define the roles of library professionals and paraprofessionals including Proposed Classification and Compensation Plans for Library Positions, The Subprofessional or Technical Assistant: A Statement of Definition, and Library Education and Personnel Utilization (LEPU). ${ }^{6}$ LEPU defined "librarian" as a professional with an MLIS. On January 23, 2002, the ALA council adopted "Library and Information Studies and Human Resource Utilization: A Statement of Policy," which formalized the acceptance of paraprofessionals as integral contributors to and participants in the library profession and advocated for a constant effort to promote the most effective utilization of personnel at all levels. ${ }^{7}$ According to this policy, the basic educational requirement for library professionals is an MLIS; additional professional degrees will be required for subject specialties. In contrast, the basic educational requirement for library paraprofessionals is bachelor's degree for library associates or two years of college-level study for library assistants. The title "librarian"

carries with it the connotation of professional in the sense that professional tasks are those which require a special background and education on the basis of which library needs are identified, problems are analyzed, goals are set, and original and creative solutions are formulated for them, integrating theory into practice, and planning, organizing, communicating, and administering successful programs of service to users of the library's materials and services. ... Positions which are primarily devoted to the routine application of established rules and techniques, however useful and essential to the effective operation of a library's ongoing services, should not carry the word Librarian in the job title.

In 1991, World Book-ALA Goal Award Project on Library Support Staff published its issue paper "Role Definition," which noted that the term "routine," which had been frequently used to differentiate between the work done by professionals and paraprofessionals in library literature, seemed inappropriate to distinguish the jobs held by a growing number of paraprofessionals whose duties required sophisticated judgment calls, supervision, and complex operations in the current library environment. ${ }^{9}$ This paper stated that "it may well be that the models and definitions which were useful in the initial development of 
paraprofessional roles no longer serve to describe the reality in a growing number of libraries."10

To understand the roles of paraprofessionals in technical services, researchers often used literature review, surveys, case studies, job advertisements, or job descriptions to do quantitative or qualitative analysis. In late 1990s, Buttlar and Garcha gleaned from literature sixty-seven traditional and emerging activities in which catalogers in academic libraries were involved and incorporated them into a questionnaire that was distributed to catalogers in academic libraries. The survey respondents indicated involvement of paraprofessionals in higher leves of cataloging. ${ }^{11}$ In 1995, Mohr and Schuneman conducted a survey of the heads of the main cataloging departments of the 119 Association of Research Libraries (ARL) institutions to examine the changing roles of paraprofessionals in original cataloging in ARL libraries. ${ }^{12}$ The results of the survey confirmed the continuing changes in assignment of original cataloging responsibilities to paraprofessionals. The survey respondents expressed concerns with increased paraprofessional involvement in original cataloging.

In 1998 and 1999, Bordeianu and Seiser conducted two surveys of ARL libraries to identify the minimum education and experience required of paraprofessional catalogers. ${ }^{13}$ The majority of surveyed libraries responded that they used paraprofessionals to catalog various types of materials. The survey results showed that a higher number of libraries used paraprofessionals in copy cataloging than in original cataloging, and some libraries hired paraprofessionals to do some jobs formerly restricted to professionals.

Smith and Etcheverria conducted a survey of directors and managers in academic library technical services departments-specifically from a sample of ARL and land-grant libraries within the United States-to examine staffing trends in technical services in academic libraries. The survey responses showed a perception of a growth in work roles for both professionals and paraprofessionals. ${ }^{14}$ Smith and Etcheverria observed,

While the literature sometimes refers to the blurring of responsibilities between professionals and paraprofessionals, survey respondents perceived that all levels of staff had grown in their positions. According to comments by respondents, areas of growth for paraprofessionals included more highlevel and original cataloging. Areas of growth for all staff included aspects of dealing with electronic resources, cataloging new formats, and growing in sophistication in use of integrated library systems. ${ }^{15}$

As a follow-up to Smith and Etcheverria's survey, Smith contacted eight of the original group surveyed because they had expressed interest in being contacted during the original survey. Smith interviewed the five who respondedand who happened to represent a cross-section of areas in technical services—and conducted a qualitative analysis. ${ }^{16}$ Smith reported that all five interviewees saw an increased or increasing role for paraprofessionals, noting, "The roles of professionals were also changing and becoming increasingly removed from day to day operations in technical services."17

Cox and Myers conducted a survey in 2008 to examine the roles of professional and paraprofessional catalogers as they were perceived by both types of catalogers. ${ }^{18}$ According to the survey findings, a majority of both professional and paraprofessional catalogers felt that paraprofessionals should do complex copy cataloging. Furthermore, 53.8 percent of professional respondents and 82.1 percent of paraprofessional respondents disagreed or strongly disagreed that original cataloging should only be handled by professionals. Cox and Myers found that the perceived distinctions between professional and paraprofessional catalogers were in the activities beyond cataloging done by professionals, such as administrative work, services on committees, and research. Cox and Myers suggested "a need in libraries for clarity in how responsibilities are defined and assigned, and how expectations are articulated, so that professional and paraprofessional catalogers better understand their roles and value to the organization." ${ }^{\prime 19}$ Cox and Myers recommended that the library profession as a whole reach consensus about the level of work paraprofessionals should do and how they should be compensated. Cox and Myers pointed out that

the roles of professionals and paraprofessionals within libraries have been in flux for more than a decade. Advances in technology have streamlined workflows, allowing staff at all levels to engage in higher-level work. Reduced budgets and the reduced staff levels that go along with them have required reshuffling of job duties and shifts in department priorities. Some of these changes have blurred the lines between professional and paraprofessional staff. Despite these shifts, the library profession still defines employees and the work they do in terms of professional librarians, requiring a master of library and information science (MLIS), and paraprofessional staff, who typically hold at least a bachelor's degree. ${ }^{20}$

Gelber and Kandarasheva discussed a case study program implemented at Columbia University Libraries (CUL) that trained paraprofessional catalogers in Program for Cooperative Cataloging (PCC) and Name Authority Cooperative Program (NACO) responsibilities. ${ }^{21}$ The CUL PCC training program proved to be a valuable investment of cataloging resources because the program contributed to the professional development of paraprofessional catalogers and 
the growth of training and mentoring skills of professional catalogers.

In 2011, Primary Research Group (PRG) published The Survey of Academic Library Cataloging Practices. ${ }^{22}$ The study looked closely at how academic libraries deployed their cataloging personnel-how they used cataloging librarians and paraprofessionals. Approximately seventy-five North American academic libraries participated in the survey. The PRG survey findings included:

- 27.3 percent of the survey participants routinely used paraprofessionals for original cataloging. Public colleges were more than three times more likely than private colleges to use paraprofessionals for original cataloging, and larger colleges were more than twice as likely as smaller ones to do so.

- 24.7 percent of the libraries in the sample use paraprofessionals for master bibliographic record enrichment in the OCLC database. Most of those doing so were public colleges and offered beyond the BA degree.

- Copy cataloging was routinely performed by paraprofessionals in 81.43 percent of libraries in the sample and by professional librarians in 58.57 percent of them.

Howarth discussed the possible future roles of paraprofessionals in various areas of technical services including selection, acquisitions, cataloging and classification, physical processing, binding and repair, and circulation, from the premise that the survival of paraprofessionals would depend on defining an occupational niche that was unique from that of clerical support staff or professional librarians. ${ }^{23}$ She observed, "Rather than being a 'shadow' librarian or a 'glorified clerk,' the paraprofessional must establish and maintain an appropriately broad, but clearly identifiable, niche to demarcate this from other levels of staff, both within technical services and the library as a whole." ${ }^{.4}$

In addition to publications on the roles of professionals and paraprofessionals in technical services, many articles have addressed related topics, including library paraprofessional movement, deprofessionalization of librarianship, inequalities between professionals and paraprofessionals, professional and paraprofessional communication and mutual respect, job satisfaction, training, continuing education, compensation, and career ladder.

Litwin reviewed the history of library support staff movement for a higher level of status in library profession and explored its implications for the professional status of librarianship in the light of sociologist Mane Haug's original work on the concept of deprofessionalization and subsequent discourse. ${ }^{25}$ Litwin observed, "Where the idea of deprofessionalization first began clearly to fit was in developments in technical services emerging later in the decade. Technology had begun to enable easy sharing of catalog records, which allowed libraries to employ fewer professional catalogers and to assign paraprofessionals the task of loading catalog records containing intellectual labor done elsewhere." ${ }^{\text {26 }}$ Litwin pointed out that deprofessionalization in technical services was accelerating-more full-time professional positions were reduced, eliminated, or replaced by paraprofessional positions, and more job duties once performed by professionals were routinely transferred to paraprofessionals. Litwin argued, "Our concern about the loss of autonomy in the library profession is not entirely a selfish concern, for two reasons: first, because a loss of autonomy for librarians is a net loss of autonomy for front-line library workers, and not simply a redistribution of it; and second, because attention to the ethical foundations of professional practice depends to a great extent on the maintenance of professional identity through a graduate education requirement and a strong professional association. ${ }^{27}$

In academic libraries, although professionals have had opportunities for career advancement via promotion and tenure, fewer systems have been in place to recognize the contribution of paraprofessionals to libraries or to encourage their professional development. Letarte, Pennell, and Hamlett reported on both research and case studies related to the growing reliance on paraprofessionals in cataloging to perform duties previously done by professionals. ${ }^{28}$ They noted, "Recent innovations in the areas of technical services have presented challenges and opportunities for new workflows. All too often, however, plans for innovative redesign of technical services units overlook the most essential components: the library's human resources, and more specifically, the support staff who accomplish the bulk of the day-to-day work in library technical services. ${ }^{29}$

Straatmann advocated addressing perceived inequalities between professionals and paraprofessionals through staff development programs that "addresses the personal, career, and competency issues facing paraprofessionals in these environments. ${ }^{30}$ Webb also advocated a similar approach. ${ }^{31}$ Webb thought that a comprehensive staff development program should include three components: competency development, career development, and personal development. Competency development includes the training of skills in technology, library services, communication, and leadership. Career development includes formal school education, continuing education after graduation, and on-the-job training. Webb felt that establishing career ladder programs to recognize paraprofessionals' skills and abilities to function in the same capacities as professionals in a variety of duties and tasks is critical. Personal development allows paraprofessionals to pursue development opportunities on their own with institutional support; through this type of development, paraprofessionals are more likely to develop a lifelong learning habit and gain more confidence in their competencies to succeed. 
Why do people accept employment as library paraprofessionals and in what ways do they find fulfillment in doing the work that is often associated with low salaries and compensation? Morrison observed that "a great majority of the paraprofessionals working in today's institutions are not there due to love of money. Many do this kind of work because they enjoy the people they work with, and because they have a dedication to the mission that libraries fulfill. It is not just for personal reasons that they do their best each and every day in the name of the best service they can provide in the best way they can." ${ }^{\prime 32}$ Bull listed the top ten reasons why she loved her job as a paraprofessional cataloger:

- challenges to work with a variety of materials

- inspiration to do more and be more

- satisfaction to complete a day's work

- opportunities to use of a variety of computer programs

- opportunities to be creative

- interesting work

- opportunities to do problem solving

- opportunities to use Internet and e-mail

- coworkers who are terrific and interesting

- library organizations and publications that offer sources of education, training, and connectivity. ${ }^{33}$

However, Grady noted that

library workers cannot live by love alone; terminal degrees can be resuscitated by professional development; libraries without staff are just buildings; and library employees are worth their salary and continuing education investments. As the association seeps into the conversation and psyches of the library workforce, there may be a future where pay equity is a nonissue, where library employees are paid comparably with their peers in other professions, and where certification is part of the natural progression of upwardly mobile librarians and support staff. ${ }^{34}$

During the past twenty years, paraprofessional issues have gained more nation- and profession-wide attention. In 1993, Association for Library Collections and Technical Services (ALCTS) established the Task Force on Meeting the Continuing Needs of Paraprofessionals to identify continuing education and training needs of paraprofessionals in collections and technical services and what ALCTS can do to meet these needs. ${ }^{35}$ As a result, ALCTS started initiatives tailored for paraprofessionals in training workshops, training the trainers, and partnerships with national, regional, and state organizations to deliver programs, publications, and information clearing house. In 1997, the ALA Library Support Staff Interests Round Table (LSSIRT) conducted a survey to determine the predominant issues facing library paraprofessionals. ${ }^{36}$ The survey indicated that the three issues of greatest concern for paraprofessionals were lack of opportunities for career advancement; compensation not appropriate for the level of required education, experience and responsibilities; and lack of access to continuing education and training opportunities. In 2001, the ALA council authorized the establishment of the ALA Allied Professional Association (ALA-APA) to "enable certification of individuals in specializations beyond the initial professional degree. In January 2002, with the approval of preliminary bylaws, the scope of the organization was broadened to include advocacy for the "mutual professional interests of librarians and other library workers.",37

In 2003, ALA's 3rd Congress on Professional Education: Focus on Library Support Staff (COPE III) made recommendations to address the top three issues of concern for paraprofessionals indicated by LSSIRT's 1997 survey in terms of association life, workplace, credentialing, education and continuing professional development, valuing people, marketing, and public relations. ${ }^{38}$ In 2005, at the ALA Annual Conference in Chicago, the ALA council adopted the ALA policy "Inclusiveness and Mutual Respect," which clearly spelled out that "ALA values, respects, and welcomes the contributions and participation of all library workers including paraprofessionals. ${ }^{39}$ In 2010, ALA-APA created the Library Support Staff Certification (LSSC) to recognize "the value of the contribution of Library Support Staff to quality public service and efficient operation of a library, by offering voluntary certification based on a nationally recognized set of competencies." defines library support staff as those who work in library positions that do not require an MLIS. LSSC is intended to help earn respect and recognition for paraprofessionals, demonstrate paraprofessionals' value to their libraries, give paraprofessionals an edge on the job or promotion, increase paraprofessionals' self-confidence, provide proof of paraprofessionals' achievement, increase paraprofessionals' understanding of library services, and help enhance paraprofessionals' service to their library users.

\section{Research Method}

In January 2011, the author conducted a survey to understand more about the roles of technical services paraprofessionals in academic libraries in the previous five years; see appendix A. For this survey, a professional position was defined as a position requiring an MLIS or equivalent. A paraprofessional position was defined as a position not requiring an MLIS or equivalent. For this survey, "technical services is defined as library functional areas that are responsible for selecting, acquiring, organizing, processing, and providing access to library collections in all formats, as opposed to the delivery 
of public services." ${ }^{" 41}$ This survey applied to both centralized and non-centralized technical services.

The survey questionnaire consisted of sixteen questions; only answers to three questions (1,2 and 5) were mandatory; twelve questions provided the opportunity to add information beyond the choices provided in the survey or to make comments. The last question was open-ended to provide an opportunity for respondents to share comments about the roles of paraprofessionals in their technical services. The survey was voluntary and respondents could withdraw from it at any time. Therefore, unless otherwise specified, the percentage quoted in this paper indicates a percentage of an individual question's respondents rather than a percentage of the total survey respondents. The percentage was rounded to one decimal point; because of rounding, the sum of percentages in tables and appendixes do not equal to 100 percent in most cases.

The survey was aimed at professionals and paraprofessionals currently working in technical services in academic libraries. On January 19, 2011, the author distributed the survey invitation via ten electronic discussion lists related to technical services: AUTOCAT, SERIALST, NGC4LIB (an interest group discussing next-generation library catalogs), OCLC-CAT, metadataLibrarians listserv, ACQNET-L, IFLA-L, IUG (an Innovative users group list), and OLACL. The e-mail invitation stated that the survey was intended for professionals and paraprofessionals working in technical services in academic libraries, provided a link to the survey hosted through SurveyMonkey (a free online survey and questionnaire tool), told recipients to feel free to forward the survey to any librarian or staff in technical services in academic libraries, and informed recipients that all responses would be kept confidential and anonymous. The survey allowed only one response per computer. After the survey was finished, the respondent would not be able to re-enter the survey, and each respondent could only enter the survey once. The survey closed February 23, 2011. The survey received 820 responses, and 512 respondents answered all questions. The author used SurveyMonkey to collect responses and perform most of the statistical analysis. Based on the IP addresses automatically collected by SurveyMonkey, 786 respondents (95.9 percent) were from the United States; 34 respondents were from other countries, including Canada, Great Britain, Australia, and New Zealand.

The author chose to administer the survey online instead of by a targeted mailing to achieve a faster response and save money. However, the author recognizes problems in surveys in which respondents are self-selected. Those who had strong opinions might be more likely to respond. The population reached might have been participating in other surveys at the time and decided to ignore this survey invitation. The size of the population (professionals and paraprofessionals in technical services in academic libraries) was unknown. Every subject in the population undoubtedly was not reached by the survey. While a simple random sampling could minimize bias, generating a sample that did not accurately reflect the makeup of the population also was possible. However, the author believes that the large number of responses to this survey can correct for these problems. Although this survey method had limitations, the author is confident that the findings present a reliable picture of the roles of paraprofessionals in academic library technical services units in recent years.

\section{Findings}

All 820 responses were analyzed. Because not all respondents answered all questions and some questions allowed more than one answer, the total number of responses for each question may be less than or greater than 820 .

\section{Respondent Demographics}

Of the 820 respondents, 368 (44.9 percent) were professionals and 452 (55.1 percent) were paraprofessionals. To find out what working titles are often used for professional and paraprofessional positions, the author gleaned from literature a list of keywords to code the working titles. Table 1 shows the coding result of the working titles of the respondents. The five most common wordings in working titles for professionals were librarian, associate librarian, assistant librarian, or deputy librarian; head, associate head, or assistant head; cataloger; director; and coordinator. The five most common wordings in working titles for paraprofessionals were library assistant or assistant; library specialist or specialist; library associate or associate; library technician or technician; and coordinator. No professional respondents had working titles (library assistant or assistant; library specialist or specialist; library associate or associate; and library technician or technician) often associated with paraprofessional positions. However, eleven paraprofessional respondents held working titles (librarian, associate librarian, assistant librarian, or deputy librarian) that might have been assigned to professional positions in the past. Several titles (head, associate head, or assistant head; director; coordinator; dean; manager; supervisor; team lead or leader; and chair) indicated leadership roles. Of the 368 professional respondents, 157 (42.7 percent) held working titles indicating leadership; only 57 (12.6 percent) of 452 paraprofessional respondents held such working titles.

\section{Technical Services Functional Areas}

Of the 729 respondents that reported the functional areas in which they work, 318 (43.6 percent) were professionals 
Table 1. Current Working Titles

\begin{tabular}{|c|c|c|c|c|c|c|}
\hline \multirow{2}{*}{$\begin{array}{l}\text { Current Working Title } \\
\text { Library assistant/Assistant }\end{array}$} & \multicolumn{2}{|c|}{$\begin{array}{l}\text { Paraprofessionals } \\
\qquad(N=452)\end{array}$} & \multicolumn{2}{|c|}{$\begin{array}{l}\text { Professionals } \\
\qquad(N=368)\end{array}$} & \multicolumn{2}{|c|}{$\begin{array}{c}\text { Total } \\
(N=820)\end{array}$} \\
\hline & 142 & $31.4 \%$ & 0 & $0.0 \%$ & 142 & $17.3 \%$ \\
\hline Library specialist/Specialist & 88 & $19.5 \%$ & 1 & $0.3 \%$ & 88 & $10.7 \%$ \\
\hline Library associate/Associate & 42 & $9.3 \%$ & 0 & $0.0 \%$ & 42 & $5.1 \%$ \\
\hline Library technician/Technician & 27 & $6.0 \%$ & 0 & $0.0 \%$ & 27 & $3.3 \%$ \\
\hline Coordinator & 25 & $5.5 \%$ & 15 & $4.1 \%$ & 40 & $4.9 \%$ \\
\hline Supervisor & 22 & $4.9 \%$ & 4 & $1.1 \%$ & 26 & $3.2 \%$ \\
\hline Manager & 18 & $4.0 \%$ & 6 & $1.6 \%$ & 24 & $2.9 \%$ \\
\hline Cataloger & 15 & $0.0 \%$ & 36 & $9.8 \%$ & 51 & $6.2 \%$ \\
\hline $\begin{array}{l}\text { Assistant cataloger/Cataloging Associate/Paraprofessional cataloger/ } \\
\text { Copy cataloger/Adaptive cataloger }\end{array}$ & 13 & $6.9 \%$ & 0 & $0.0 \%$ & 13 & $1.6 \%$ \\
\hline Librarian/Associate librarian/Assistant librarian/Deputy librarian & 11 & $2.4 \%$ & 195 & $53.0 \%$ & 206 & $25.2 \%$ \\
\hline Head/Associate head/Assistant head & 10 & $2.2 \%$ & 86 & $23.4 \%$ & 96 & $11.7 \%$ \\
\hline Paraprofessional & 9 & $2.0 \%$ & 0 & $0.0 \%$ & 9 & $1.1 \%$ \\
\hline Support & 5 & $1.1 \%$ & 0 & $0.0 \%$ & 5 & $0.6 \%$ \\
\hline Administrator (systems/electronic resources) & 3 & $1.0 \%$ & 0 & $0.0 \%$ & 3 & $0.4 \%$ \\
\hline Director & 1 & $0.2 \%$ & 34 & $9.2 \%$ & 35 & $4.3 \%$ \\
\hline Team lead/Leader & 1 & $0.2 \%$ & 4 & $1.1 \%$ & 5 & $0.6 \%$ \\
\hline Dean & 0 & $0.0 \%$ & 6 & $1.6 \%$ & 6 & $0.7 \%$ \\
\hline Professor & 0 & $0.0 \%$ & 6 & $1.6 \%$ & 6 & $0.7 \%$ \\
\hline
\end{tabular}

Note: Respondents' working titles could contain more than one keyword listed in table 1; therefore total responses might exceed $N$.

Table 2. Technical Services Functional Areas

\begin{tabular}{|c|c|c|c|c|c|c|}
\hline \multirow{2}{*}{$\begin{array}{l}\text { Functional Area } \\
\text { Cataloging }\end{array}$} & \multicolumn{2}{|c|}{$\begin{array}{l}\text { Paraprofessionals } \\
\qquad(N=411)\end{array}$} & \multicolumn{2}{|c|}{$\begin{array}{l}\text { Professionals } \\
\quad(N=318)\end{array}$} & \multicolumn{2}{|c|}{$\begin{array}{c}\text { Total } \\
(N=729)\end{array}$} \\
\hline & 305 & $74.2 \%$ & 247 & $77.7 \%$ & 552 & $75.7 \%$ \\
\hline Acquisitions & 169 & $41.1 \%$ & 121 & $38.1 \%$ & 290 & $39.8 \%$ \\
\hline Physical processing & 147 & $35.8 \%$ & 79 & $24.8 \%$ & 226 & $31.0 \%$ \\
\hline Electronic resources management & 135 & $32.8 \%$ & 115 & $36.2 \%$ & 250 & $34.3 \%$ \\
\hline Print serials (check-in, claiming, binding, etc.) & 122 & $29.7 \%$ & 76 & $23.9 \%$ & 198 & $27.2 \%$ \\
\hline Management/Administration/Supervision & 80 & $19.5 \%$ & 137 & $43.1 \%$ & 217 & $29.8 \%$ \\
\hline Collections & 74 & $18.0 \%$ & 103 & $32.4 \%$ & 177 & $24.3 \%$ \\
\hline Documents (federal, state, international, etc.) & 57 & $13.9 \%$ & 40 & $12.6 \%$ & 97 & $13.3 \%$ \\
\hline Preservation & 57 & $13.9 \%$ & 36 & $11.9 \%$ & 93 & $12.8 \%$ \\
\hline
\end{tabular}

Note: Respondents could choose multiple areas; therefore total responses exceed $\mathrm{N}$.

and 411 (56.4 percent) were paraprofessionals. Because most respondents were working in more than one functional area, they could check as many choices as applied (see table 2 ). Based on the comments, some respondents also had responsibilities in nontraditional technical services areas, including automated systems, reference, digital collections, interlibrary loan, special collections, non-MARC metadata, fundraising, institutional repository, circulation, assessment, accounting, and bibliographic instruction.

\section{Changes in Position Numbers and Types}

More than half (60.6 percent) of respondents who answered the questions about increases or decreases in the number 
Table 3. Changes in Number of Positions during the Last Five Years

\begin{tabular}{|c|c|c|c|c|c|c|}
\hline \multirow{2}{*}{$\begin{array}{l}\text { Change in Total Number of Positions } \\
\text { Decreased }\end{array}$} & \multicolumn{2}{|c|}{$\begin{array}{l}\text { Paraprofessionals } \\
\qquad(N=405)\end{array}$} & \multicolumn{2}{|c|}{$\begin{array}{l}\text { Professionals } \\
\qquad(N=315)\end{array}$} & \multicolumn{2}{|c|}{$\begin{array}{c}\text { Total } \\
(N=720)\end{array}$} \\
\hline & 255 & $63.0 \%$ & 181 & $57.5 \%$ & 436 & $60.6 \%$ \\
\hline Remained the same & 113 & $28.0 \%$ & 100 & $31.7 \%$ & 213 & $29.6 \%$ \\
\hline Increased & 37 & $9.1 \%$ & 34 & $10.8 \%$ & 71 & $9.9 \%$ \\
\hline Change in Number of Professional Positions & \multicolumn{2}{|c|}{$\begin{array}{l}\text { Paraprofessionals } \\
\qquad(N=403)\end{array}$} & \multicolumn{2}{|c|}{$\begin{array}{l}\text { Professionals } \\
\quad(N=315)\end{array}$} & \multicolumn{2}{|c|}{$\begin{array}{c}\text { Total } \\
(N=718)\end{array}$} \\
\hline Decreased & 140 & $34.8 \%$ & 92 & $29.2 \%$ & 232 & $32.3 \%$ \\
\hline Remained the same & 198 & $49.1 \%$ & 185 & $45.9 \%$ & 383 & $53.3 \%$ \\
\hline Increased & 65 & $16.1 \%$ & 38 & $12.1 \%$ & 103 & $14.3 \%$ \\
\hline Change in Number of Paraprofessional Positions & \multicolumn{2}{|c|}{$\begin{array}{l}\text { Paraprofessionals } \\
\qquad(N=405)\end{array}$} & \multicolumn{2}{|c|}{$\begin{array}{l}\text { Professionals } \\
\qquad(N=314)\end{array}$} & \multicolumn{2}{|c|}{$\begin{array}{c}\text { Total } \\
(N=719)\end{array}$} \\
\hline Decreased & 228 & $56.3 \%$ & 168 & $53.5 \%$ & 396 & $55.1 \%$ \\
\hline Remained the same & 141 & $34.8 \%$ & 119 & $37.9 \%$ & 260 & $36.2 \%$ \\
\hline Increased & 36 & $8.9 \%$ & 27 & $8.6 \%$ & 63 & $8.8 \%$ \\
\hline
\end{tabular}

of positions in their technical services units during the previous five years reported an overall decrease; 29.6 percent reported no change and only 9.9 percent reported an increase (see table 3 ). Of the 720 who responded to this question, 315 (43.8 percent) respondents were professionals and 405 (56.3 percent) were paraprofessionals. Because the survey was anonymous, the author could not find out how many respondents were from the same libraries. Thus all the percentages in table 3 only reflect the percentages of the total responses of each individual question.

In the comment area of the survey, some respondents gave details about causes for decreases in positions, including the following:

- Technical services lost positions because of departures, layoffs, and retirements. Vacant positions in technical services were not filled or were eliminated completely because of a hiring freeze, budget cuts, downsizing, retirement incentives/buyouts, or reorganization.

- Vacated positions in technical services were moved to other departments. Technical services staff were transferred to other teams or departments because of reorganization or new initiatives.

- The same workload was apportioned among decreased staff in technical services. When a person left, no replacement was added, but the job duties were taken on by the rest of the department.

- Positions were demoted from professional to paraprofessional. Positions were reduced from full-time to part-time.

- Technical services outsourced some of its servic- es, such as copy cataloging. Technical services used more advanced technology and software to save staff resources.

Some respondents explained what caused the increase of positions, such as new information needs, information reorganization, and greater workload.

The question regarding an increase or decrease in professional positions in technical services drew 718 responses (see table 3). Slightly more than half of the respondents (53.3 percent) reported that the number of professional positions remained the same during the previous five years, 32.3 percent reported a decrease, and only 14.3 percent reported an increase. Some respondents commented that they had no professional positions in technical services.

Some respondents explained what caused the decrease of professional positions in technical services, noting that professional positions were promoted to administrative positions, vacant professional positions were not being filled, and, while the number of professional positions remained the same, more professionals were hired to do nontraditional technical services work, such as information technology, digital initiatives, and institutional repository.

Some respondents gave reasons for the increase of professional positions in technical services:

- Technical services gained more professional positions to do work in nontraditional technical services areas such as digital initiatives, institutional repository, metadata, digital preservation, information technology, electronic resource management, and licensing.

- Technical services gained more professional positions 
Table 4. Required Education

\begin{tabular}{|c|c|c|c|c|}
\hline Level of Education & \multicolumn{2}{|c|}{$\begin{array}{l}\text { Paraprofessionals } \\
\qquad(N=452)\end{array}$} & \multicolumn{2}{|c|}{$\begin{array}{l}\text { Professionals } \\
\quad(N=368)\end{array}$} \\
\hline Bachelors degree & 214 & $47.4 \%$ & 10 & $2.7 \%$ \\
\hline High school graduation or equivalent & 128 & $28.3 \%$ & 4 & $1.1 \%$ \\
\hline Required educational degree is not specified in my job description & 87 & $19.2 \%$ & 0 & $0.0 \%$ \\
\hline Library associate degree & 31 & $6.9 \%$ & 0 & $0.0 \%$ \\
\hline Graduate degree (not in library and information science) & 17 & $3.8 \%$ & 11 & $3.0 \%$ \\
\hline Masters degree in library and information science or equivalent & 0 & $0.0 \%$ & 368 & $100 \%$ \\
\hline
\end{tabular}

Note: Respondents could choose multiple degrees; therefore total responses exceed N.

because of reorganization or library expansion.

- Professional positions were filled when vacant, but paraprofessional positions were not.

- Paraprofessional positions that had been doing much higher levels of work were promoted to professional positions.

- Nonprofessional positions were replaced by professional positions.

- The number of professional positions remained the same, but administrative level positions were lost and replaced with entry-level positions with a focus on new skills.

- Paraprofessional positions were promoted to professional positions after employees received an MLIS. In some cases, the people working in paraprofessional positions had an MLIS. The administration decided to change their position titles to librarians, and they became classified as professionals even though they were doing the work of paraprofessionals.

Slightly more than half (55.1 percent) of the 719 respondents to the question about increases or decreases in paraprofessional positions reported that the number of paraprofessional positions in their technical services units had decreased, 36.2 percent reported no change, and 8.8 percent reported an increase (see table 3 ). One respondent mentioned that his or her technical services unit had no paraprofessional positions.

Respondents who commented on causes for the decrease in paraprofessional positions identified the following reasons:

- Professional positions absorbed the work of paraprofessionals.

- Paraprofessional positions were reclassified as professional positions when vacant.

- Technical services eliminated paraprofessional positions that were no longer needed.

- Technical services hired more students for processing.
Reasons for an increase in paraprofessional positions in technical services included paraprofessionals moving to technical services for reasons not related to needing another staff person in technical services, and the library increasing space and collection size because more students were attending the university.

\section{Required Education and Skills Sets}

All 820 responded to the question about degrees required (see table 4). All professionals reporting that an MLIS or its equivalent was required for their positions, and none of the paraprofessionals reported such a requirement. Among the 452 paraprofessional responses, 214 (47.4 percent) paraprofessional positions required a bachelor's degree, 17 (3.8 percent) required graduate degrees (not in library and information science), and 31 (6.9 percent) required a library associate degree. Other educational requirements for paraprofessional positions listed by respondents were associate degrees in other subject fields, some college credits, two years' college diploma or certification, computer certification, a combination of education and experience that is equivalent to library associate or library technician degrees, library technician diploma, or a combination of education and experience that can substitute for degree requirements.

The survey asked if respondents held degrees higher than the degrees required for their positions; 813 responded, 368 (45.3 percent) of which were professionals and 445 (54.7 percent) of which were paraprofessionals. Of the 445 paraprofessional respondents, 315 (70.8 percent) held degrees higher than the degrees required for their positions; only 69 of the professionals (18.8 percent) held degrees higher than the degrees required for their positions.

One question explored high-level skills required according to individuals' official job descriptions, to which 747 responded. Of these, 329 (44 percent) were professionals and 418 (56 percent) were paraprofessionals. Table 
Table 5. Required High-Level Skills

\begin{tabular}{|c|c|c|c|c|c|c|}
\hline \multirow{2}{*}{$\begin{array}{l}\text { Skills } \\
\text { Computer skills }\end{array}$} & \multicolumn{2}{|c|}{$\begin{array}{l}\text { Paraprofessionals } \\
\qquad(N=418)\end{array}$} & \multicolumn{2}{|c|}{$\begin{array}{l}\text { Professionals } \\
\quad(N=329)\end{array}$} & \multicolumn{2}{|c|}{$\begin{array}{l}\text { Total } \\
(N=747)\end{array}$} \\
\hline & 405 & $96.9 \%$ & 291 & $88.4 \%$ & 696 & $93.2 \%$ \\
\hline Ability to work independently & 392 & $93.8 \%$ & 282 & $85.7 \%$ & 674 & $90.2 \%$ \\
\hline Management/supervisory/personnel skills & 380 & $90.9 \%$ & 233 & $70.8 \%$ & 403 & $53.9 \%$ \\
\hline Communication skills (oral/written) & 364 & $87.1 \%$ & 303 & $92.1 \%$ & 667 & $89.3 \%$ \\
\hline Interpersonal/human relations skills & 296 & $70.8 \%$ & 262 & $79.6 \%$ & 558 & $74.7 \%$ \\
\hline Teamwork/team leadership skills & 271 & $64.8 \%$ & 236 & $71.7 \%$ & 507 & $67.9 \%$ \\
\hline $\begin{array}{l}\text { Knowledge in current issues/trends/best practices/standards/technology in techni- } \\
\text { cal services }\end{array}$ & 241 & $57.7 \%$ & 287 & $87.2 \%$ & 528 & $70.7 \%$ \\
\hline Ability to implement/manage technological/organizational change & 238 & $56.9 \%$ & 239 & $72.6 \%$ & 477 & $63.9 \%$ \\
\hline Project management skills & 182 & $43.5 \%$ & 199 & $60.5 \%$ & 381 & $51.0 \%$ \\
\hline Problem-solving skills & 151 & $36.1 \%$ & 269 & $81.8 \%$ & 624 & $83.5 \%$ \\
\hline Administrative/leadership skills & 124 & $29.7 \%$ & 222 & $67.5 \%$ & 346 & $46.3 \%$ \\
\hline Foreign language skills & 104 & $24.9 \%$ & 100 & $30.4 \%$ & 204 & $27.3 \%$ \\
\hline Budgeting skills & 86 & $20.6 \%$ & 119 & $36.2 \%$ & 205 & $27.4 \%$ \\
\hline
\end{tabular}

Note: Respondents could choose multiple areas; therefore total responses exceed $\mathrm{N}$.

5 presents the findings. The ten most frequently required skills for paraprofessional positions (in rank order) were

- computer skills

- ability to work independently

- management/supervisory/personnel skills

- communication skills (oral/written)

- analytical skills

- interpersonal/human relations skills

- teamwork/team leadership skills

- knowledge in current issues/trends/best practices/ standards/technology in technical services

- ability to implement/manage technological/organizational change

- training/mentoring skills

The ten most frequently required skills for professional positions (also in rank order) were

- communication skills (oral/written)

- computer skills

- knowledge in current issues/trends/best practices/ standards/technology in technical services

- ability to work independently

- problem-solving skills
- interpersonal/human relations skills

- analytical skills

- ability to implement/manage technological/organizational change

- teamwork/team leadership skills

- management/supervisory/personnel skills

When the two groups of respondents were combined, the top three skills were computer skills, ability to work independently, and communication skills.

Table 5 shows little difference in high-level skills required for professional positions and paraprofessional positions. The ten most frequently required skills for professional and paraprofessional positions are almost identical, though the ranking orders are different. In addition to the skills listed as choices in the survey, respondents identified other required skills, including position-specific skills (cataloging, reference, public services, teaching, data management, math, license negotiation, and library instruction) and general skills (research, organizational, time management, multitasking, detail-oriented, and service-oriented).

One question investigated complex duties regularly assigned (i.e., officially part of the job description) to the respondents' positions in technical services, either full- or part-time; 666 responded. Of these, 293 (44 percent) were 
professionals and 373 (56 percent) were paraprofessionals. Appendix B presents the findings. The ten complex duties most frequently assigned to paraprofessional positions, either full- or part-time, were the following:

- Act as one of the primary resources for issues in your job duty areas.

- Keep current on trends and developments in your job duty.

- Act as one of the primary trainers in your job duty areas.

- Act as one of the primary liaisons to librarians, staff, vendors, publishers, or library users in your job duty areas.

- Take the lead in/make major contribution to developing/implementing policies/standards/goals/procedures to improve workflow in your job duty areas.

- Troubleshoot/solve problems involving intensive application and knowledge of library policies and procedures, national standards, vendor systems, or publisher licenses.

- Serve on library working groups, committees, task forces, etc.

- Attend workshops, institutes, seminars, or conferences at local, state, regional, national or international levels.

- Perform complex copy cataloging that requires subject analysis and/or classification.

- Assign subject/genre headings.

The ten complex duties most frequently assigned to professional positions, either full or part time, were the following:

- Keep current on trends and developments in your job duty areas.

- Act as one of the primary resources for issues in your job duty areas.

- Attend workshops, institutes, seminars, or conferences at local, state, regional, national or international levels.

- Serve on library working groups, committees, task forces, etc.

- Take the lead in/make major contribution to developing/implementing policies/standards/goals/procedures to improve workflow in your job duty areas.

- Participate in professional organizations.

- Troubleshoot/solve problems involving intensive application and knowledge of library policies and procedures, national standards, vendor systems, or publisher licenses.

- Act as one of the primary liaisons to librarians, staff, vendors, publishers, or library users in your job duty areas.
- Act as one of the primary trainers in your job duty areas.

- Perform complex copy cataloging that requires subject analysis or classification or both.

These two lists are almost identical, though the ranking orders are different. Paraprofessionals have been involved in almost all the complex duties in technical services. One noticeable difference is that, while 80.2 percent of professional positions required participation in professional organizations, only 19 percent of paraprofessional positions had such a requirement. Another noticeable difference is that, for almost all the complex duties listed, the percentages under paraprofessionals are much lower than the percentages under professionals.

The survey sought to learn the extent to which complex duties assigned to paraprofessionals had changed during the previous five years. Responses are presented in appendix C. Of the 520 respondents, 50 percent or more of respondents in libraries that have complex duties assigned to paraprofessionals reported that the roles of paraprofessionals had expanded in fourteen areas; these are indicated in grey boxes in appendix C. Four responsibilities increased the most:

- Take the lead in/make major contribution to the management of electronic resources.

- Identify or test electronic resources, including both subscription/purchases and open access titles.

- Troubleshoot complex e-access problems.

- Manage or troubleshoot problems in link resolvers.

Respondents identified nine areas in which paraprofessionals had no responsibilities. The complex duties not assigned to paraprofessionals noted by 80 percent or more of respondents were the following:

- Conduct research for publications or presentations in areas of library and information science or other scholarly subjects.

- Take the lead in/make major contribution to the preparation of grant proposals.

- Take the lead in/make major contribution to institutional repository.

- Take the lead in/make major contribution to scholarly communication.

- Establish collection development policies.

- Take the lead in/make major contribution to negotiating licensing for electronic resources.

- Sign licenses for electronic resources.

- Resolve complex copyright issues.

- Create/implement the preservation plan for digital resources. 
Table 6. Incentives Offered to Technical Services Paraprofessionals for Staff Development

\begin{tabular}{|c|c|c|}
\hline Incentive & \multicolumn{2}{|c|}{$\begin{array}{l}\text { Responses } \\
(N=485)\end{array}$} \\
\hline $\begin{array}{l}\text { In-house training, e.g., workshops, free webi- } \\
\text { nars/online courses, learning breaks, presenta- } \\
\text { tions }\end{array}$ & 444 & $91.5 \%$ \\
\hline $\begin{array}{l}\text { Release time to attend local, state, regional con- } \\
\text { ferences, workshops, etc. }\end{array}$ & 386 & $79.6 \%$ \\
\hline $\begin{array}{l}\text { Release time to attend national conferences, } \\
\text { workshops, etc. }\end{array}$ & 186 & $38.4 \%$ \\
\hline $\begin{array}{l}\text { Funding to attend local, state, regional confer- } \\
\text { ences, workshops, etc. }\end{array}$ & 295 & $60.8 \%$ \\
\hline $\begin{array}{l}\text { Funding to attend national conferences, work- } \\
\text { shops, etc. }\end{array}$ & 133 & $27.4 \%$ \\
\hline Funding to attend paid webinars/online courses & 288 & $59.4 \%$ \\
\hline $\begin{array}{l}\text { Systematic training for newly hired/transferred } \\
\text { paraprofessional staff }\end{array}$ & 230 & $47.4 \%$ \\
\hline Each staff has a training allotment each year & 51 & $10.5 \%$ \\
\hline
\end{tabular}

Note: Respondents could choose multiple areas; therefore total responses exceed $N$.

No respondents reported that the complex duties assigned to paraprofessionals significantly declined in the past five year. In the comment area, respondents noted that duties with metadata have gone up, but very few paraprofessionals were involved. In some case, paraprofessionals were union members, and union contract agreements at times restricted paraprofessionals' responsibilities. In one case, paraprofessionals with MLIS degrees performed higher-level work. They contributed much more than was expected of other paraprofessionals and were held to a higher standard.

\section{Incentives for Paraprofessional Staff Development}

The question about incentives offered to technical services paraprofessional for staff development received 485 responses (see table 6). The five most frequently offered incentives were

- in-house training;

- release time to attend local, state, regional conferences, workshops, etc.;

- funding to attend local, state, regional conferences, workshops, etc.;

- funding to attend paid webinars/online courses; and

- systematic training for newly hired/transferred paraprofessional staff.

Libraries less frequently offered release time and funding for paraprofessionals to attend national conferences
Table 7. Incentives Offered to Paraprofessionals to Seek an MLIS

Responses

$(N=395)$

\begin{tabular}{lcc} 
Release time for classes & 140 & $35.4 \%$ \\
\hline Work schedule adjustment & 333 & $84.3 \%$ \\
\hline $\begin{array}{l}\text { Tuition remission/reimbursement } \\
\text { Rehire in a professional position upon gradu- } \\
\text { ation }\end{array}$ & 173 & $43.8 \%$ \\
\hline Mentoring by professional librarians & 157 & $4.1 \%$ \\
\hline
\end{tabular}

Note: Respondents could choose multiple areas; therefore total responses exceed $N$.

and workshops; this might be because of their higher cost. Only three responded that their libraries offered no incentives to paraprofessional staff for staff development. Most respondents' libraries offered support for in-house training or release time or funding to attend local conferences, workshops, and seminars. However, libraries rarely provided funding for paraprofessionals to attend national conferences, workshops, and seminars. Comments noted that budget constraints in recent years had decreased or completely ended the support for staff development in many respondents' libraries.

Support to seek a MLIS is an obvious incentive supporting paraprofessional staff development and can be offered in various ways. Only 395 responded to a question about the type of support offered (see table 7). The most frequently offered incentive was work schedule adjustment. Less frequently offered were tuition remissions or reimbursement, mentoring by professional librarians, and release time for classes. Libraries rarely offered to rehire paraprofessionals into professional positions upon graduation. Thirty-three respondents did not know if their library offered incentives to paraprofessionals who would like to get an MLIS or stated that no incentives were offered to paraprofessionals for this purpose. Comments indicated that the support in those libraries that offered some incentives to paraprofessionals who would like to get MLIS was often viewed as minimal, inadequate, or unstable.

\section{General Comments from Survey Respondents}

The survey concluded with an open-ended question asking respondents to share any additional thoughts about the roles of paraprofessionals in their technical services, and 116 offered comments. Most said that their libraries had pushed paraprofessionals to do more complex duties because of budget cuts, hiring freezes, layoffs, reorganization, technological changes, or library priority changes (or a combination of these). They reported that more of the day-to-day work in technical services was being done by paraprofessionals while 
professionals focused more on administration, management, research, outreach, new initiatives, services, committee work, and policy-making. In some libraries, almost all cataloging work was done by paraprofessionals, including copy cataloging, original cataloging, and some authority work. However, high-level authority work, including Program for Cooperative Cataloging (PCC), Name Authority Cooperative Program (NACO), and Subject Authority Cooperative Program (SACO) responsibilities remained with librarians in most cases. Meanwhile, an increasing amount of work previously undertaken by paraprofessionals was passed to temporary employees and student assistants. Although duties typically transferred from professionals to paraprofessionals, some noted that the transfer had been done the other way, too. Who does what in technical services in academic libraries was mostly determined at the local level.

One respondent pointed out that technical service was a mixture of routine work punctuated by extremely complex problems that could crop up without warning. Finding routine tasks where complex problem solving skills were not needed was becoming more difficult. Another respondent pointed out that all of the roles in technical services were changing with the growing emphasis on electronic resources instead of print. Staff had to be savvier at handling new duties in new ways. Although many said that the role of paraprofessionals had been expanded in terms of complex duties, one argued that the role of paraprofessionals had been diminishing because more job duties required the broader background and greater expertise of professionals. The amount of routine work that could be taught once and then performed repetitively by paraprofessionals had declined; many more situations demanded informed vision and constant evaluation. One respondent pointed out that emerging technologies and the move from print to digital collections would require a higher ratio of professional to paraprofessional staff. Many commented that paraprofessionals had always been an important part of technical services. For the most part, paraprofessionals tended to remain in their positions for a long time, giving them significant experience; therefore assigning more responsibilities based on their experience was easy. The line between paraprofessional duties and professional duties had not been rigid, and duties tended to be assigned according to a person's abilities. Several mentioned that, because of poor job markets, paraprofessional positions were often filled by people with MLIS degrees.

Many noticed that while the duties assigned to paraprofessionals had increased, the number of paraprofessionals had decreased in their libraries, and the authority to make decisions had become the responsibility of only the top-level paraprofessionals. One commented that administration in his or her library showed no respect for paraprofessionals in technical services and discouraged paraprofessionals' involvement in decision-making. Policy decisions were made without consultation with paraprofessionals who actually did the work, creating frustration and chaos. One mentioned that some professionals felt threatened by the fact that paraprofessionals were doing more complex duties. Some mentioned that libraries lay off paraprofessionals and use the money to hire professionals; meanwhile, the remaining paraprofessionals had to pick up the responsibilities of those laid off paraprofessionals. Some pointed out that their position descriptions did not always accurately reflect all they did in their daily work. In many cases, position descriptions had a section for other duties as assigned or related duties. Many of the high-level complex tasks including planning, documentation, researching, and implementation of new technology were done by paraprofessionals because they would not otherwise be done due to of lack of staffing, even though those duties were not specified in their position descriptions. Some respondents suggested that libraries should involve paraprofessionals in information-seeking, planning, and decision-making processes, which would encourage buy-in to changes and facilitate implementation.

Many commented that, although paraprofessionals took on more high-level duties that were once the sole provinces of professionals, they had not been compensated at the same level as professionals. In addition, paraprofessionals often were expected to have a higher production rate. Some said that they were concerned about losing their jobs in the current poor economic situation as much as they were concerned about receiving compensation for the additional duties they took on. Those who were at the top paraprofessional levels often did the same level of complex work as professionals for a lower salary and without the same benefits and staff development opportunities the professionals had. Some mentioned that professional and paraprofessional roles had been a contentious issue at their libraries. Paraprofessionals had taken on increasing responsibilities without increases in compensation. Professional positions were filled with recent MLIS graduates who needed time to develop but that had been assigned the task of coordinating paraprofessionals who had greater expertise and more experience. These factors left many paraprofessionals feeling undervalued. The conflict led to low morale, breakdowns in communication, and resistance to changes initiated by professionals.

Many saw a disconnect between allowing paraprofessionals to evolve and grow to the professional level and their opportunities. While the duties of paraprofessionals had increased quite dramatically, library administration in most libraries offered little to no support for promotion. Some wished that their staff classification systems could have more levels so that they had more chances for promotion. One noted that, in his or her library, if a paraprofessional reached the top of the classification system, he or she had nowhere to go without getting an MLIS. One commented 
that because his or her library did not have a staff classification system, paraprofessionals had no form of advancement other than annual cost of living increase, if they were lucky. One mentioned the frustration over the lack of support to those paraprofessionals who had the knowledge to do the job but lacked the money to get an MLIS. To some, taking on student loans for a degree with such low future income potential and even questionable employment perspectives seemed unwise.

Most of the responses in this section reported a belief that libraries did not provide adequate training for paraprofessionals and that little support for staff development was present. One mentioned that when the number of professional catalogers was reduced, paraprofessionals had to take over duties formerly performed by professionals, but no funding was available for giving them more training. One noted that the only professional left in the department was expected to do all original cataloging, train paraprofessionals, and review their work. This was impossible; as a result, paraprofessionals had to do the best they could with inadequate training. Quality was no longer considered important and even basic accuracy was sometimes optional. One commented that paraprofessionals were required to do more work but were given less chance to attend library organization meetings and training unless they paid their own way, which was not possible on a paraprofessional salary.

Several expressed their concern about being called "paraprofessional." One commented that, as a manager of a major unit, considering him- or herself a paraprofessional was difficult. This individual considered himself or herself a "professional without an MLIS." Many observed that all library staff needed to be treated with respect because, by necessity, they worked as equals.

\section{Discussion}

The survey findings show that paraprofessionals were performing duties across all functional areas in technical services, including electronic resources management. In addition to duties in traditional technical services functions, some paraprofessionals had duties in archives and manuscript collections, integrated library system management, interlibrary loan, creation of finding aids, reference desk work, website maintenance, institutional repository, software development, and digital collections.

The survey findings about educational degrees required for professional and paraprofessional positions echoed what had been reported in library literature-only professional positions required an MLIS. Among the survey respondents, all professional positions required an MLIS or equivalent and none of the paraprofessional positions had such a requirement. Paraprofessionals arrived in their jobs with a wide variety of educational backgrounds. More than half of paraprofessional respondents held educational degrees that were higher than those required for their positions. In the previous five years, library paraprofessionals were still defined as library employees who did not have an MLIS. "Librarian" was a working title that had been used almost exclusively for library professionals.

The author initially assumed that high-level skills required for paraprofessional positions were likely to differ from those required for professional positions. However, the survey findings proved otherwise, with little difference in high-level skills required for professional and paraprofessional positions. The ten most frequently required skills for both positions are almost identical, though the ranking orders are different. One noticeable difference is that knowledge of issues, trends, best practices, standards, and technology in technical services; problem solving skills; and administration and leadership skills were much more frequently required for professionals than paraprofessionals. In contrast, management and supervisory skills were more frequently required for paraprofessionals than for professionals.

The survey findings about complex duties regularly assigned to professional and paraprofessional positions covered complex duties in most areas of technical services. The author was not surprised to find that paraprofessionals were involved in complex duties - the library literature had noted this trend. However, the author was surprised that the ten complex duties most frequently assigned to professional and to paraprofessional positions were almost identical, although the ranking orders were different. One noticeable difference is that, while most professional positions required participation in professional organizations, service on regional and national committees, research, and publication, few paraprofessional positions had such requirements. The second noticeable difference is that, although the top ten complex duties were similar for both groups, the percentages of employees with these duties were much lower for paraprofessionals than for professionals. Without a follow-up study, one cannot know the reasons for these differences. The third noticeable difference is that, in comparison with professional positions, only a small percentage of paraprofessional positions (less than 20 percent) had the responsibility to perform several complex duties.

In libraries that had complex duties assigned to paraprofessionals, the roles of paraprofessionals expanded in most of these libraries. This is consistent with findings in earlier research. No respondents reported that the complex duties assigned to paraprofessionals significantly declined in the past five years. Seven libraries reported that responsibility of signing licenses for electronic resources had been reduced. This responsibility showed the greatest area of reduction, but the change only affected 13.5 percent of the libraries in this group. Respondents were not asked the reason, but one 
might posit that libraries became more conscious of the legal implications of signing license agreements.

The survey findings will contribute to the ongoing discussion of issues related to paraprofessionals in technical services. According to the ALA, library professionals should perform tasks "which require a special background and education on the basis of which library needs are identified, problems are analyzed, goals are set, and original and creative solutions are formulated for them, integrating theory into practice, and planning, organizing, communicating, and administering successful programs of service to users of the library's materials and services." ${ }^{42}$

In technical services, rapid changes in technology and telecommunication have meant that some duties formerly performed by professionals have become more routine and established; thus they have been passed to paraprofessionals while professionals move on to new initiatives and services. However, this transition has not always been precise. As more duties in technical services have required the broader background and greater expertise of professionals, the amount of routine work that can be taught once and then performed repetitively by paraprofessionals has decreased. The survey findings show that paraprofessionals have taken on high-level complex duties that cannot be labeled routine because those duties require special training, knowledge, and experience; high-level creativity and originality; and good problem solving, communication, and analytical skills. The roles of professionals and paraprofessionals have not been clearly delineated as both professionals and paraprofessionals continue to grow in knowledge and skills. As Lopatin observed, "While support staff have taken on much of the routine work, and even some of the more complex tasks once the sole purview of professionals, technical services librarians have assumed wider roles, both within and outside technical services. Shrinking resources and rising user expectations of library services are factors in this trend." ${ }^{33}$ Further, Smith and Echeverria noted, "This points to a movement away from traditional roles in technical services staffs at all levels; the bar is raised for everyone in relation to technology." ${ }^{44}$ The lines between professionals and paraprofessionals have been blurred, and this trend will continue. As more technical services duties and tasks demand informed vision, complex problem solving, good communication, and constant evaluation, technical services units will need a higher ratio of professionals and high-level paraprofessionals to lowlevel paraprofessionals. The library profession as a whole must recognize that paraprofessionals have been doing tasks previously performed by professionals and address the urgent need to resolve long-standing issues, including the appropriate use of paraprofessionals, appropriate compensation and career ladders for paraprofessionals, staff development, pay equality, and role definition.
To understand more about paraprofessionals in technical services, further research on the following topics is needed:

- roles for professionals and paraprofessionals in various functional areas

- renovation of staff classification systems to meet current and future needs of library services in terms of job titles; required education, skills, knowledge, and experience; job duties; criteria for promotion; and compensation

- career paths for paraprofessionals

- certification for paraprofessionals

- core competencies for paraprofessionals

- pay equality for paraprofessionals

- training and continuing education for paraprofessionals

- communication and mutual respect among professionals and paraprofessionals

\section{Conclusion}

This paper has reported the results of a survey the author conducted to understand more about the roles of technical services paraprofessionals in academic libraries in the previous five years. The intent was to gain insight into the roles of paraprofessionals in academic library technical services operations through a survey of professionals and paraprofessionals. Findings support what has been reported in library literature. The roles of paraprofessionals include high-level complex work formerly under the sole purview of professionals. The roles of both professionals and paraprofessionals have evolved and expanded. The lines between professional duties and paraprofessional duties have blurred. The main distinction between professional work and paraprofessional work often arise in areas outside traditional technical services work, such as administration, service on university and national committees, new initiatives, new technology, research, and publication. Because of rapid changes in the environment, more technical services duties are requiring "independent judgment; interpretation of rules and procedures; analysis of library problems; and formulation of original and creative solutions for them.. ${ }^{35}$ Outsourcing and technology advances mean that routine duties that can be taught once and done repetitively following established procedures are decreasing drastically in technical services. This shift suggests that soon technical services units will need a higher ratio of professionals and high-level paraprofessionals to low-level paraprofessionals.

Despite the changes documented here, the library profession still defines library employees and the work they do in terms of professionals (librarians) who have an MILS and paraprofessionals who do not have an MLIS. The 
library profession should recognize this is no longer sufficient. This author recommends that the library profession as a whole reach consensus about the roles of professionals and paraprofessionals, the level of work professionals and paraprofessionals should do, how professionals and paraprofessionals should be compensated, and what the library profession should do for the continuing education and career ladders for both professionals and paraprofessionals.

\section{References}

1. Joan M. Reitz, ODLIS Online Dictionary for Library and Information Science, s.v. "Paraprofessional," www.abc-clio. com/ODLIS/odlis_p.aspx (accessed Oct. 13, 2011).

2. Larry R. Oberg, "Library Support Staff in an Age of Change: Utilization, Role Definition, and Status," EDOIR-95-4 (May 1995), www.ala.org/educationcareers/ education/3rdcongressonpro/librarysupportstaffage (accessed Oct. 13, 2011).

3. Sharon E. Clark, "Managing Copy Cataloging in ARL Libraries," SPEC Flyer 136 (July-Aug. 1987); Michael A. Oliker, "The Deprofessionalization Story and the Future of Technical Services," Illinois Libraries 72, no. 6 (Sept. 1990): 472-78; Jennifer A. Young, "The Role of Librarians in Bibliographic Access Services in the 1990s," Journal of Library Administration 15, no. 1-2 (1991): 125-50; Clair-Lise Benaud, "The Academic Paraprofessional Cataloger: Underappreciated?" Cataloging \& Classification Quarterly 15, no. 3 (1992): 81-92; James S. Chervinko, “The Changing State of Original Cataloging: Who's Going to Do It Now?" Illinois Libraries 74 (Dec. 1992): 493-95; Larry R. Oberg et al., "The Role, Status, and Working Conditions of Paraprofessionals: A National Survey of Academic Libraries," College \& Research Libraries 53 (1992): 215-38; William E. Benemann, "The Cathedral Factor: Excellence and the Motivation of Cataloging Staff," Technical Services Quarterly 10, no. 3 (1993): 17-25; May Rider, "Developing New Roles for Paraprofessionals in Cataloging," Journal of Academic Librarianship 22, no. 1 (1996): 26-32; Carol P. Johnson, "The Changing Nature of Jobs: A Paraprofessional Time Series, "College \& Research Libraries 57 (Jan. 1996): 59-67; Jennifer A. Young, "Support Staff and Librarians in Cataloging," Cataloging \& Classification Quarterly 23, no. 1 (1996): 27-47; Nadine P. Ellero, "The Name and Role of the Cataloger in the Twenty-First Century," in Innovative Redesign and Reorganization of Library Technical Services, ed. Bradford Lee Eden, 119-55 (Westport, Conn.: Libraries Unlimited, 2004); David Banush, "Stepping Out: The Expanding Role of Catalogers in Academic Libraries and Academic Institutions" Cataloging \& Classification Quarterly 45, no. 3 (2008): 81-90; Colleen Valente, "Training Successful Paraprofessional Copy Catalogers," Library Resources \& Technical Services 53 no. 4 (Oct. 2009): 219-30; Edna McClellan, "Stress and Cataloging Paraprofessionals in Academic and Public Libraries in Florida," Southeastern Librarian 59, no. 1 (Spring 2011): 20-29.

4. Oberg, "Library Support Staff in an Age of Change."

5. Charles C. Williamson, Training for Library Service: A
Report Prepared for the Carnegie Corporation of New York (New York: Carnegie, 1923).

6. Bureau of Public Personnel Administration, Proposed Classification and Compensation Plans for Library Positions: Report of the Bureau of Public Personnel Administration to the Committee on the Classification of Library Personnel of the American Library Association (Washington, D.C.: Bureau of Public Personnel Administration, 1927); American Library Association Interdivisional Ad Hoc Committee of the Library Education Division and the Library Administration Division, "The Subprofessional or Technical Assistant: a Statement of Definition," ALA Bulletin 62, no. 4 (Apr. 1968): 387-97; American Library Association, Library Education and Personnel Utilization: A Statement of Policy Adopted by the Council of the American Library Association, June 30, 1970 (Chicago: Office for Library Personnel Resources, ALA, 1970).

7. American Library Association, "Library and Information Studies and Human Resource Utilization: A Statement of Policy Adopted by the Council of the American Library Association, January 23, 2002," www.ala.org/ala/aboutala/offices/ hrdr/educprofdev/lepu.pdf (accessed Oct. 13, 2011).

8. Ibid.

9. American Library Association Office for Library Personnel Resources Standing Committee on Library Education, World Book-ALA Goal Award Project on Library Support Staff, "Role Definition," Issue Paper no. 9 (Sept. 17, 1991), www.ala.org/educationcareers/education/3rdcongressonpro/ roledefinition (accessed Oct. 14, 2011)

10. Ibid.

11. Lois J. Buttlar and Rajinder Garcha, "Catalogers in Academic Libraries: Their Evolving and Expanding Roles," College d Research Libraries 59, no. 4 (July 1998): 311-21.

12. Deborah A. Mohr and Anita P. Schuneman, "Changing Roles: Original Cataloging by Paraprofessionals in ARL Libraries," Library Resources \& Technical Services 41 (July 1997): 20518.

13. Sever Michael Bordeianu and Virginia Seiser, "Paraprofessional Catalogers in ARL libraries: Results of a Survey," College \& Research Libraries, 60, no. 6 (Nov. 1999): 532-40.

14. Vicki Toy Smith and Kathryn Etcheverria, "Staffing Trends in Academic Library Technical Services," in Innovative Redesign and Reorganization of Library Technical Services: Paths for the Future and Case Studies, ed. Bradford Lee Eden, 41-51 (Westport, Conn.: Libraries Unlimited, 2004).

15. Ibid., 44.

16. Vicki Toy Smith, "Staffing Trends in Academic Library Technical Services: A Qualitative Analysis," in More Innovative Redesign and Reorganization of Library Technical Services, ed. Bradford Lee Eden, 95-105 (Westport, Conn.: Libraries Unlimited, 2009).

17. Ibid., 100.

18. Elizabeth J. Cox and Ann K. D. Myers, "What is a Professional Cataloger? Perception Differences between Professionals and Paraprofessionals," Library Resources \& Technical Services 54, no. 4 (Oct. 2010): 212-26.

19. Ibid., 221.

20. Ibid., 212. 
21. Natalia Gelber and Irina Kandarasheva, "Notes on Operations PCC Training for Copy catalogers: Is It Worth the Investments? The Columbia University Libraries Experience," Library Resources of Technical Services 55, no. 3 (2011):163-71.

22. Primary Research Group, The Survey of Academic Library Cataloging Practices, 2011-12 ed. (New York: Primary Research Group, 2011).

23. Lynne Christine Howarth, "The Role of the Paraprofessional in Technical Services in Libraries," Library Trends 46, no. 3 (Winter 1998): 526-39.

24. Ibid., 583.

25. Rory Litwin, "The Library Paraprofessional Movement and the Deprofessionalization of Librarianship," revised edition, Jan. 27, 2010, www.libraryjuicepress.com/docs/deprofessionalization.pdf (accessed Jan. 2, 2012), originally published in Progressive Librarian no. 33 (Summer/Fall 2009): 43-60.

26. This version is slightly revised from the originally published version.

27. Ibid.

28. Ibid.

29. Karen M. Letarte, Charles Pennell, and Shirley Hamlett, "Creating Career Paths for Cataloging Support Staff," in Innovative Redesign and Reorganization of Library Technical Services: Paths for the Future and Case Studies, ed. Bradford Lee Eden, 275-305 (Westport, Conn.: Libraries Unlimited, 2004).

30. Ibid., 275.

31. Michael Straatmann, "Addressing Perceived Inequalities between Academic Library Faculty and Paraprofessionals through Staff Development Programs," Nebraska Library Association Quarterly 39, no. 1 (Spring 2008): 3.

32. Jo Webb, "Development Routes for Academic Library Support Staff," in Developing Academic Library Staff for Future Success, ed. Margaret Oldroyd, 95-111 (London: Facet, 2004).

33. Douglas Morrison, "In the Name of Service," American Libraries 39, no. 6 (June/July 2008): 51.

34. Jennifer Bull, "The Top Ten Reasons Why I Love My Job," Library Mosaics 12, no. 4 (July/August 2001): 16-17.

35. Jenifer Grady, “Answering the Calls of 'What's Next' and
'Library Workers Cannot Live by Love Alone' through Certification and Salary Research," Library Trends 58, no. 2 (Fall 2009): 243.

36. American Library Association ALCTS Task Force on Meeting the Continuing Needs of Paraprofessionals, "ALCTS Task Force on Meeting the Continuing Needs of Paraprofessionals Report, 1995," www.ala.org/ala/mgrps/divs/alcts/resources/ meetingcontinuing.cfm (accessed Jan. 2, 2012).

37. American Library Association Library Support Staff Interests Round Table, "ALA Library Support Staff Interests Round Table Issues Survey," www.ala.org/lssirt/lssirtstratplan/issuessurvey/issuessurvey (accessed Jan. 2, 2012).

38. ALA-APA, "About ALA-APA," http://ala-apa.org/about-alaapa (accessed Nov. 24, 2011).

39. American Library Association, "3rd Congress on Professional Education: Focus on Library Support Staff: Report of the Steering Committee, June 2003," www.ala.org/educationcareers/sites/ala.org.educationcareers/files/content/ education/3rdcongressonpro/COPE3Final_Report.pdf (accessed Jan. 2, 2012).

40. American Library Association, "Inclusiveness and Mutual Respect," www.ala.org/ala/aboutala/governance/policymanual/updatedpolicymanual/ocrpdfofprm/54-7inclusiveness.pdf (accessed Jan 2, 2012).

41. American Library Association, "Library Support Staff Certification, FAQ," http://ala-apa.org/lssc/faq/\#1 (accessed Oct. 17, 2011).

42. Lihong Zhu, "Use of Teams in Technical Services in Academic Libraries," Library Collections, Acquisitions, \& Technical Services 35, no. 2/3 (2011): 72.

43. American Library Association, "Library and Information Studies and Human Resource Utilization," 4.

44. Laurie Lopatin, "Review of the Literature: Technical Services Redesign and Reorganization," in Innovative Redesign and Reorganization of Library Technical Services: Paths for the Future and Case Studies, ed. Bradford Lee Eden, 3-25 (Westport, Conn.: Libraries Unlimited, 2004): 6.

45. Smith and Etcheverria, "Staffing Trends in Academic Library Technical Services,” 42.

46. American Library Association, "Library and Information Studies and Human Resource Utilization,” 3.

\section{Appendix A. Survey Questions}

\section{Introduction}

You are invited to participate in an online survey about the role of paraprofessionals in technical services in academic libraries. This survey is intended for both professionals and paraprofessionals who are working in technical services in academic libraries. For this survey, a professional position is defined as a position requiring a master's degree in library science/information science or equivalent. A paraprofessional position is defined as a position not requiring a master's degree in library science/information science or equivalent. Typical paraprofessional positions include library associates, library clerks, library assistants, library technicians, library paraprofessionals, or library support staff. Paraprofessional positions could also be management positions, such as unit heads, supervisors, and coordinators.

For this survey, "technical services" is defined as library functional areas that are responsible for selecting, acquiring, organizing, processing, and providing access to library collections in all formats, as opposed to the delivery of public services. Typical technical services functional areas include collection development, cataloging, acquisitions, electronic resources 
management, physical processing, print serials (checkin, binding, claiming, etc.), documents, and preservation. In some libraries, technical services functional areas are centralized and belong to one unit/department/division; in some libraries, technical services functional areas are not centralized and belong to different units/departments/divisions. This survey applies to both centralized and non-centralized technical services.

Library literature noted that more and more complex duties were assigned to library paraprofessionals in technical services in academic libraries. The purpose of this survey is to identify the type of complex duties assigned to paraprofessionals in technical services in academic libraries and to what extent paraprofessionals perform library work that has been considered professional.

Responding to this survey constitutes informed consent to participating in the research. The survey is voluntary, and you may withdraw from it at any time. All responses will be kept confidential and anonymous. The results of this survey are intended for publication.

The survey will remain open until February 23, 2011. It should take around 30 minutes to complete. Please feel free to forward this survey to any librarian or staff who is working in technical services in academic libraries.

If you have any questions, please feel free to contact Lihong Zhu, Head of Technical Services, Washington State University, e-mail: lzhu2@wsu.edu.

Thank you for your participation.

Q1. What is your current working title?

Q2. What educational degree(s) does your position require according to your official position description?

Required educational degree is not specified in my job description

Master's degree in library science/information science or equivalent

Graduate degree (not in library science/information science)

Library associate degree

O Bachelor's degree

High School graduation or equivalent

Other (Please specify)

Q3. Do you hold educational degrees that are higher than the educational degree required for your position?

$\mathrm{O}$ Yes

O No

Q4. What high-level skills and competencies are required for your position according to your official job description? Select as many as apply.

O Ability to be innovative/creative

O Ability to implement/manage technological/organizational change

O Ability to work independently

O Administrative/leadership skills

O Analytical skills

O Budgeting skills

Communication skills (oral/written)

O Computer skills

Foreign language skills

Interpersonal/human relations skills

Knowledge in current issues/trends/best practices/standards/technology in technical services

O Management/supervisory/personnel skills

O Planning skills

O Problem-solving skills

O Project management skills

O Teamwork/team leadership skills

O Training/mentoring skills

Other (please specify) 
Q5. Which technical services functional areas are you currently working in? Please check as many as apply.

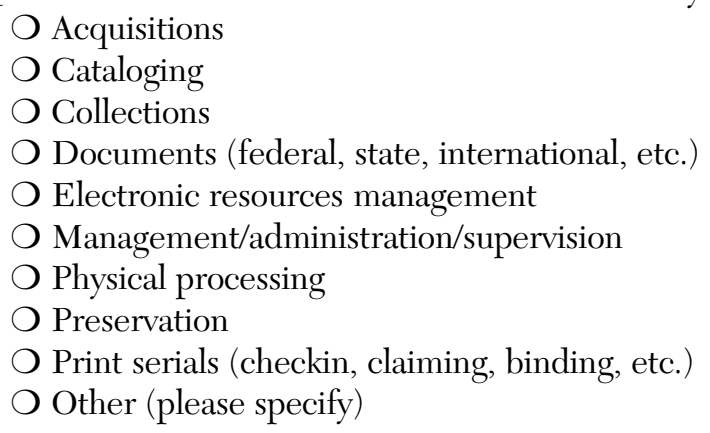

Q6. In the past 5 years, did your technical services have a net increase or decrease in positions?

Increase

O Decrease

O Remain the same

Could you give more details?

Q7. In the past 5 years, did your technical services have a net increase or decrease in professional positions? For this survey, a professional position is defined as a position requiring a master's degree in library science/information science or equivalent.

Increase

O Decrease

Remain the same

Could you give more details?

Q8. In the past 5 years, did your technical services have a net increase or decrease in paraprofessional positions? For this survey, a paraprofessional position is defined as a position not requiring a master's degree in library science/information science or equivalent. Typical paraprofessional positions include library associates, library clerks, library assistants, library technicians, library paraprofessionals, or library support staff. Paraprofessional positions could also be management positions, such as unit heads, supervisors, and coordinators.

Increase

O Decrease

O Remain the same

Could you give more details?

Q9. Please indicate which of the following complex duties are regularly assigned (i.e., officially part of the job description) to your position in technical services, either full or part time. Please check as many as apply.

O Supervise/coordinate technical services on a daily basis

O Supervise/coordinate a unit in technical services on a daily basis (e.g., cataloging unit, acquisitions unit)

Supervise/coordinate only specific duties within a unit in technical services on a daily basis (e.g., cataloging serials, monograph ordering)

Take the lead in/make major contribution to developing/implementing policies/standards/goals/procedures to improve workflow in your job duty areas

Take the lead in/make major contribution to researching/implementing new information technology in your job duty areas

Keep current on trends and developments in your job duty areas

Act as one of the primary resources for issues in your job duty areas

Act as one of the primary trainers in your job duty areas

Troubleshoot/solve problems involving intensive application and knowledge of library policies and procedures, national standards, vendor systems, or publisher licenses

Act as one of the primary liaisons to librarians, staff, vendors, publishers, or library users in your job duty areas

Act as a project/team/group/task force/committee leader

Participate in professional organizations 
Attend workshops, institutes, seminars or conferences at local, state, regional, national or international levels

Conduct research for publications or presentations in areas of library and information science or other scholarly subjects

Take the lead in/make major contribution to the preparation of grant proposals

O Serve on library working groups, committees, task forces, etc.

O Serve on university/college committees, task forces, etc.

Have the signing authority for acquisition reports, invoices, purchase card logs, etc.

Manage acquisitions budget

O Perform complex copy cataloging that requires subject analysis and/or classification

P Perform original cataloging: descriptive

O Perform original cataloging: subject analysis

P Perform original cataloging: classification

O Assign LC/Dewey call numbers

O Assign subject/genre headings

O Perform authority work on a regular basis

Create original authority records

O Create original metadata with Dublin Core or other metadata schema

O Review coworkers' original cataloging

O Perform complicated database maintenance

Take the lead in/make major contribution to digital initiatives

Take the lead in/make major contribution to institutional repository

Take the lead in/make major contribution to scholarly communication

O Select/de-select materials as part of collection development

O Perform collection analysis/assessment/evaluation

O Establish collection development policies

O Manage collection budget, e.g., planning, allocation, tracking, balancing, setting cancellation target, etc.

Take the lead in/make major contribution to the management of electronic resources

Identify or test electronic resources, including both subscription/purchase and open access titles

Take the lead in/make major contribution to negotiating licensing for electronic resources

O Sign licenses for electronic resources

Take the lead in/make major contribution to managing existing licensing for electronic resources

Monitor subscriptions in relation to existing license expirations and renewals

Review the impact of current licensing on post cancellation archival access

Arrange for registration and activation of electronic subscriptions

Troubleshoot complex e-access problems

O Manage or troubleshoot problems in vendor electronic resources management modules

O Manage or troubleshoot problems in link resolvers

O Manage or troubleshoot problems in metasearch engines

O Manage or troubleshoot problems in ILS (integrated library systems)

Manage or troubleshoot problems in library discovery interface or OPAC

Take the lead in/make major contribution to collecting usage statistics

Resolve complex copyright issues

Allocate binding budget

Take the lead in/make major contribution to establishing/implementing library preservation plan

Create/implement the preservation plan for digital resources

Establish priorities and procedures for the care and maintenance of the research collection

Take the lead in/make major contribution to creating/implementing the emergency preparedness plan

O Other complex duties (please specify)

Q10. Consider the roles/job descriptions of paraprofessionals in your technical services in the past 5 years. Please indicate whether paraprofessionals in your technical services had roles in the past 5 years in each of the following listed complex duties/responsibilities. If they had, had their roles expanded, grown smaller, or remained the same in the past 5 years in each of the following listed complex duties/responsibilities? 


\section{Duty/Responsibility}

Supervise/coordinate technical services on a daily basis

Supervise/coordinate a unit in technical services on a daily basis (e.g., cataloging unit, acquisitions unit)

Supervise/coordinate only specific duties within a unit in technical services on a daily basis (e.g., cataloging serials, monograph ordering)

Take the lead in/make major contribution to developing/ implementing policies/standards/goals/procedures to improve workflow

Take the lead in/make major contribution to researching/ implementing new information technology

Keep current on trends and developments

Act as one of the primary resources for issues

Act as one of the primary trainers

Troubleshoot/solve problems involving intensive application and knowledge of library policies and procedures, national standards, vendor systems, or publisher licenses

Act as one of the primary liaisons to librarians, staff, vendors, publishers, or library users

Act as a project/team/group/task force/committee leader

Participate in professional organizations

Attend workshops, institutes, seminars or conferences at local, state, regional, national or international levels

Conduct research for publications or presentations in areas of library and information science or other scholarly subjects

Take the lead in/make major contribution to the preparation of grant proposals

Serve on library working groups, committees, task forces, etc.

Serve on university/college committees, task forces, etc.

Have the signing authority for acquisition reports, invoices, purchase card logs, etc.

Manage acquisitions budget

Perform complex copy cataloging that requires subject analysis and/or classification

Perform original cataloging: descriptive

Perform original cataloging: subject analysis

Perform original cataloging: classification

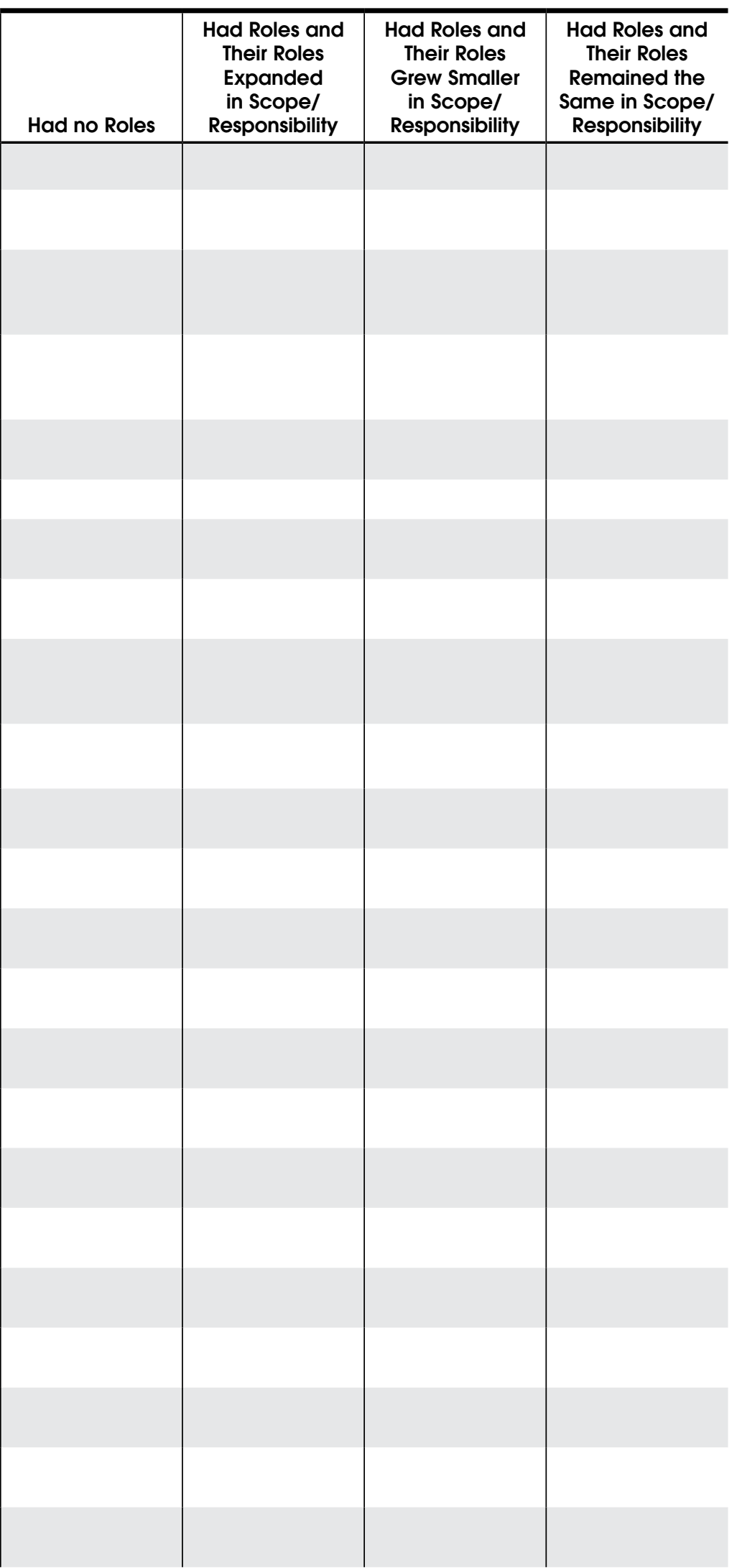




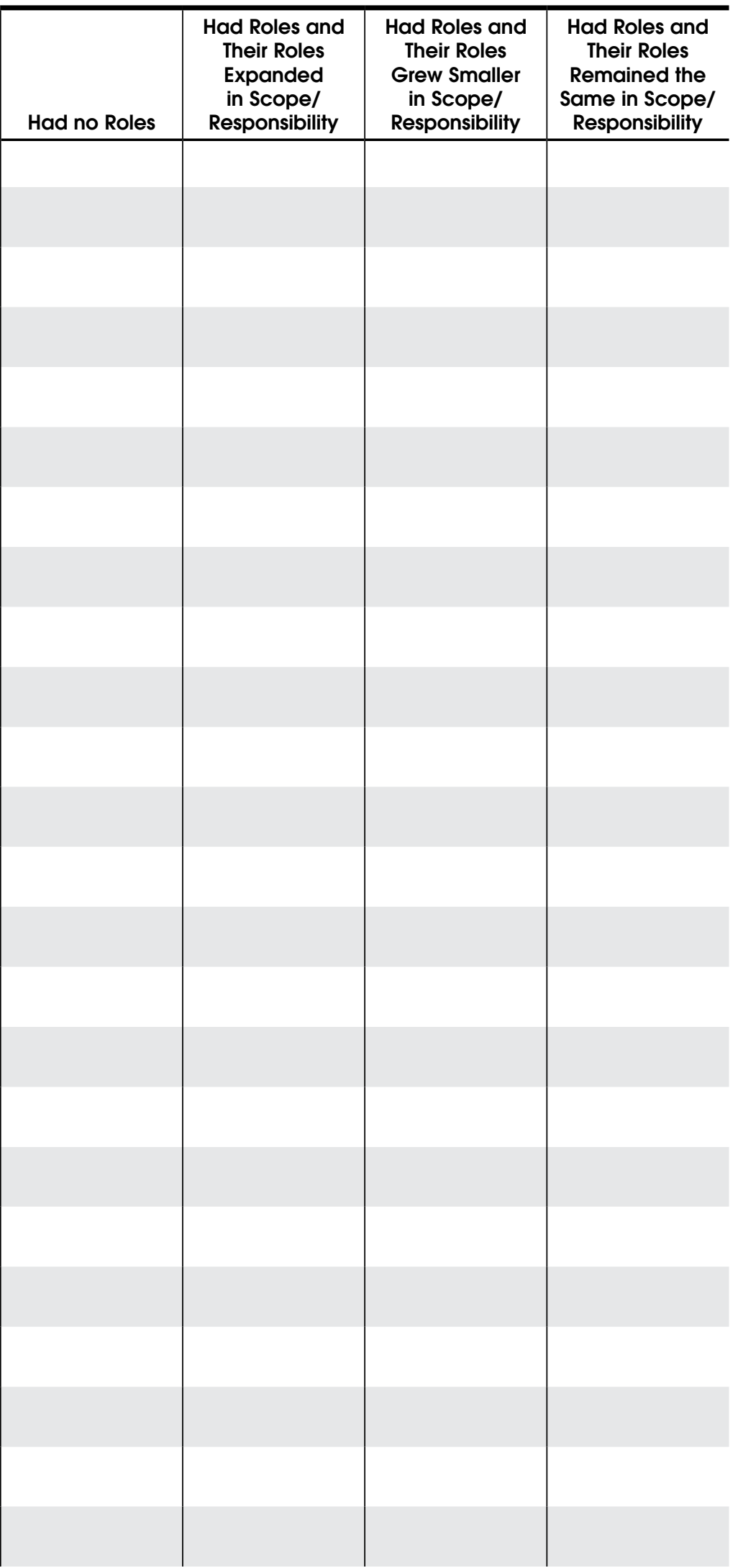

Manage or troubleshoot problems in vendor electronic resources management modules 


\begin{tabular}{|c|c|c|c|c|}
\hline Duty/Responsibility & Had no Roles & $\begin{array}{l}\text { Had Roles and } \\
\text { Their Roles } \\
\text { Expanded } \\
\text { in Scope/ } \\
\text { Responsibility }\end{array}$ & $\begin{array}{l}\text { Had Roles and } \\
\text { Their Roles } \\
\text { Grew Smaller } \\
\text { in Scope/ } \\
\text { Responsibility }\end{array}$ & $\begin{array}{l}\text { Had Roles and } \\
\text { Their Roles } \\
\text { Remained the } \\
\text { Same in Scope/ } \\
\text { Responsibility }\end{array}$ \\
\hline \multicolumn{5}{|l|}{ Manage or troubleshoot problems in link resolvers } \\
\hline \multicolumn{5}{|l|}{ Manage or troubleshoot problems in metasearch engines } \\
\hline \multicolumn{5}{|l|}{$\begin{array}{l}\text { Manage or troubleshoot problems in ILS (integrated library } \\
\text { systems) }\end{array}$} \\
\hline \multicolumn{5}{|l|}{$\begin{array}{l}\text { Manage or troubleshoot problems in library discovery inter- } \\
\text { face or OPAC }\end{array}$} \\
\hline \multicolumn{5}{|l|}{$\begin{array}{l}\text { Take the lead in/make major contribution to collecting usage } \\
\text { statistics }\end{array}$} \\
\hline \multicolumn{5}{|l|}{ Allocate binding budget } \\
\hline \multicolumn{5}{|l|}{$\begin{array}{l}\text { Take the lead in/make major contribution to establishing/ } \\
\text { implementing library preservation plan }\end{array}$} \\
\hline \multicolumn{5}{|l|}{ Create/implement the preservation plan for digital resources } \\
\hline \multicolumn{5}{|l|}{$\begin{array}{l}\text { Establish priorities and procedures for the care and mainte- } \\
\text { nance of the research collection }\end{array}$} \\
\hline $\begin{array}{l}\text { Take the lead in/make major contribution to creating/imple- } \\
\text { menting the emergency preparedness plan }\end{array}$ & & & & \\
\hline
\end{tabular}

Q11. Does your library use a classified position system for library paraprofessional staff?

O Yes

No

Q12. If you answered Yes to question 11, what is your library-specific paraprofessional staff classification system called? Could you provide the url for the classification system?

Q13. How many levels of library-specific paraprofessional staff classification do you have in your library? (e.g., In a library, the paraprofessional staff are classified by library \& archives paraprofessional 1,2,3,4,5, and 6; thus, there are 6 levels of library-specific paraprofessional staff classification in this library.) How many levels of library-specific paraprofessional staff classification do you have in your library? (e.g., In a library, the paraprofessional staff are classified by library \& archives paraprofessional 1,2,3,4,5, and 6 ; thus, there are 6 levels of library-specific paraprofessional staff classification in this library.)

Q14. What incentives does your library offer to paraprofessional staff in technical services for staff development?

O In-house training, e.g., workshops, free webinars/online courses, learning breaks, presentations

O Released time to attend local, state, regional conferences, workshops, etc.

O Released time to attend national conferences, workshops, etc.

F Funding to attend local, state, regional conferences, workshops, etc.

Funding to attend national conferences, workshops, etc.

F Funding to attend paid webinars/online courses

Systematic training for newly hired/transferred paraprofessional staff

Each staff has a training allotment each year

Q15. What incentives does your library offer to paraprofessional staff who would like to seek a master degree in library science/information science? 
Release time for classes

Work schedule adjustment

O Tuition remission/reimbursement

Rehire in a professional position upon graduation

Mentoring by professional librarians

Q16. If you would like to share anything else about the evolving role of paraprofessionals in your technical services, please feel free to do so.

\section{Appendix B. Complex Duties Regularly Assigned}

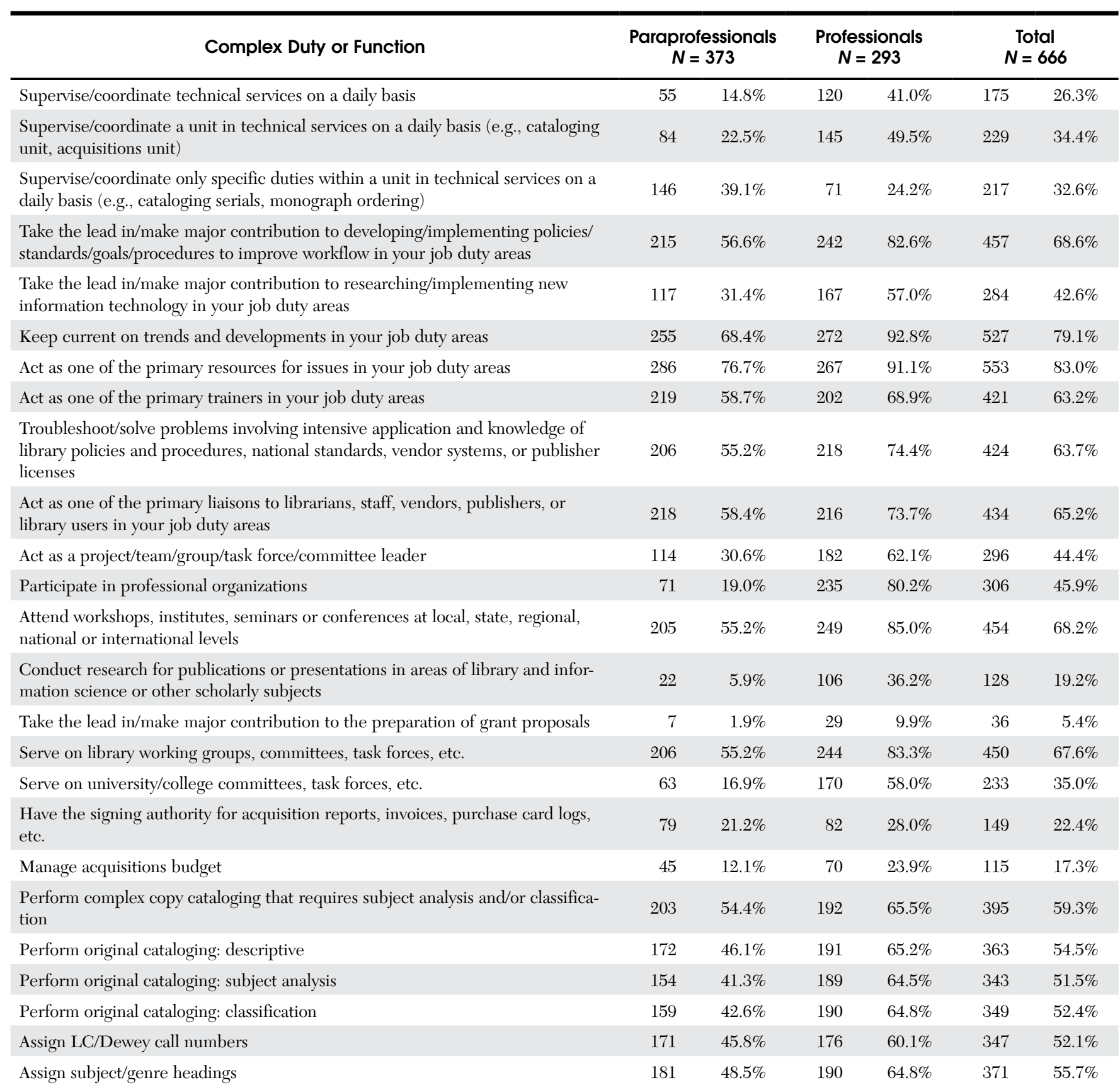




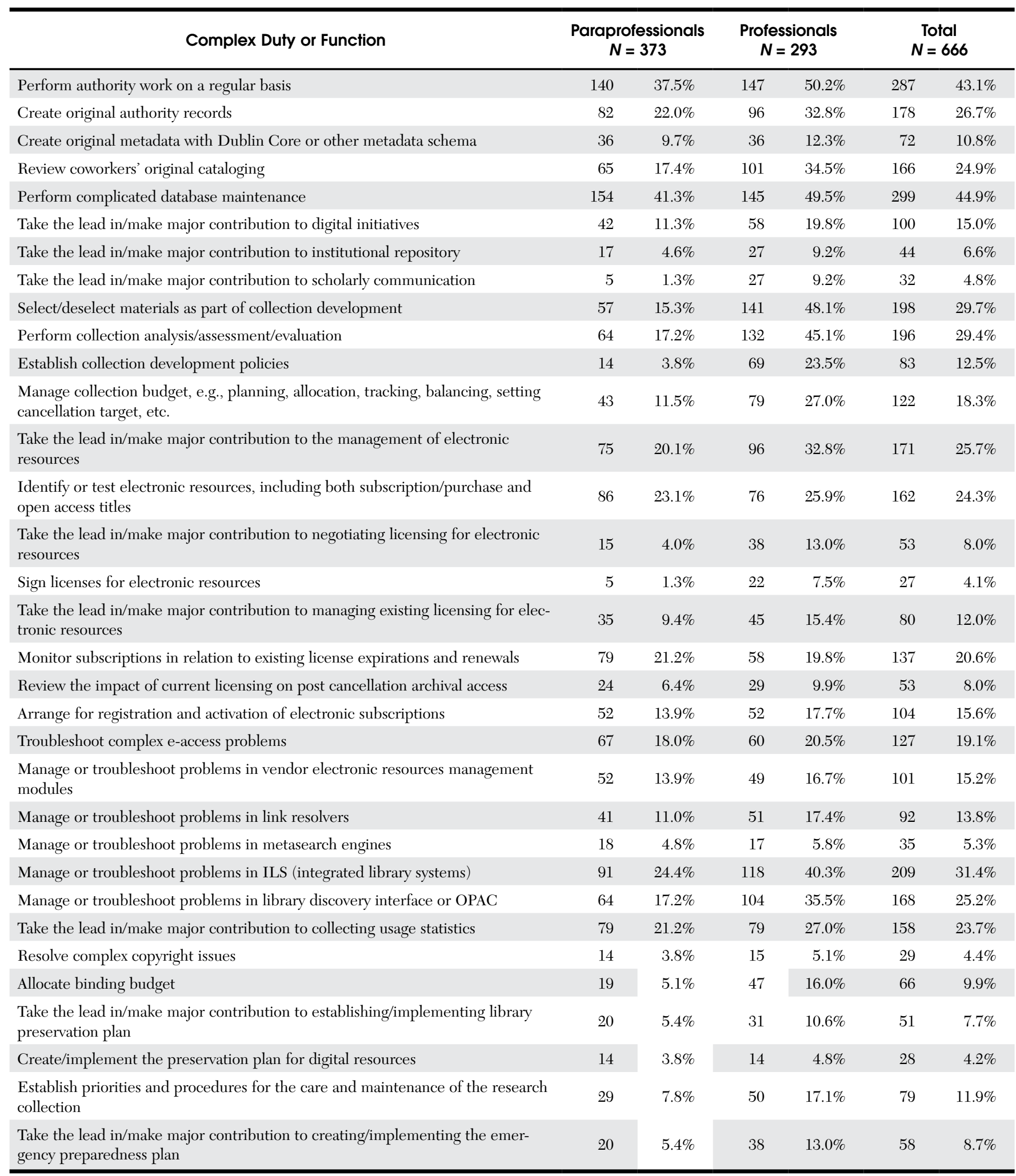

Note: Respondents could choose multiple areas; therefore total responses exceed $\mathrm{N}$. 


\section{Appendix C. Changes in Complex Duties Assigned to Paraprofessionals during Previous Five Years}

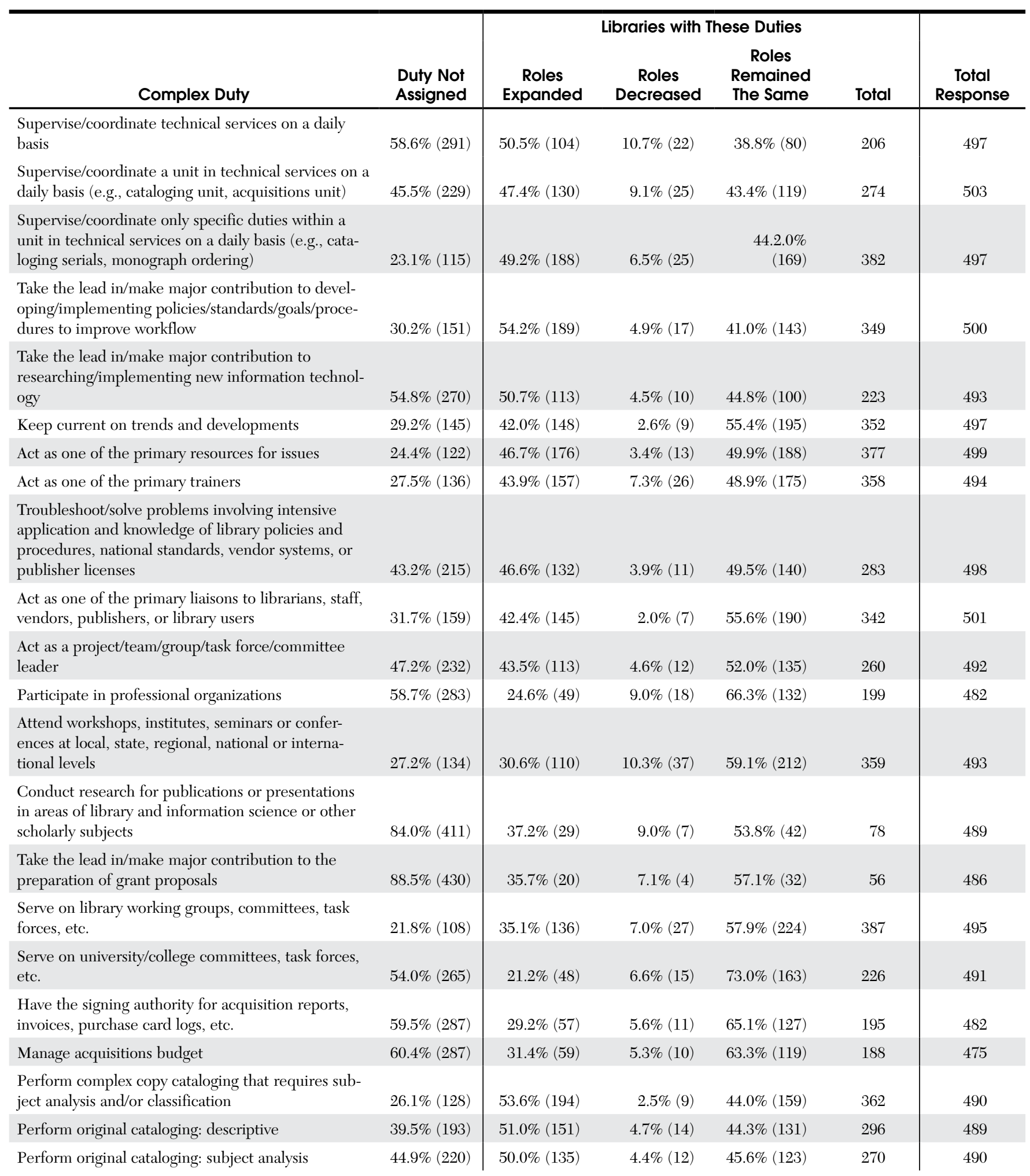




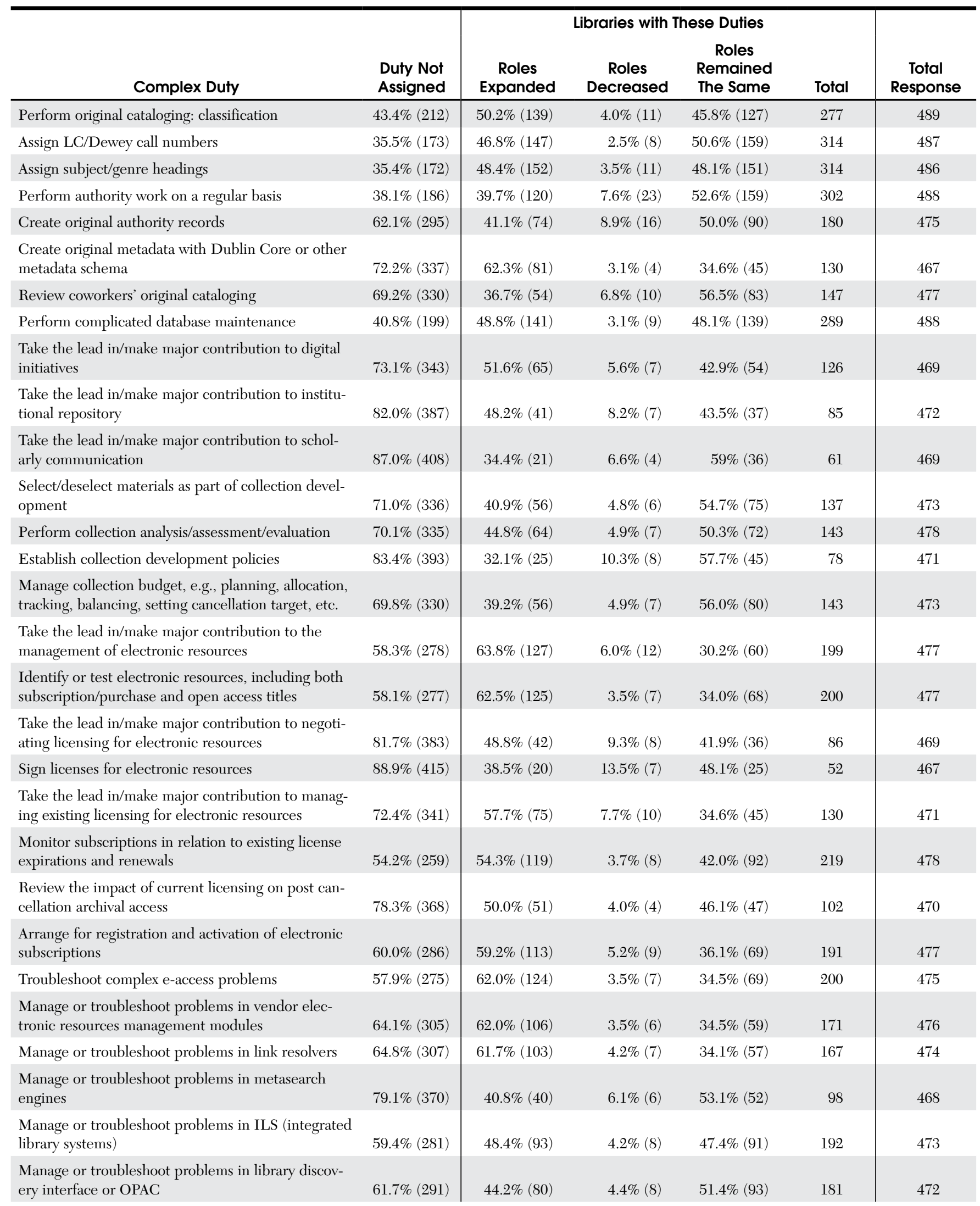




\begin{tabular}{|c|c|c|c|c|c|c|}
\hline Complex Duty & $\begin{array}{l}\text { Duty Not } \\
\text { Assigned }\end{array}$ & $\begin{array}{l}\text { Roles } \\
\text { Expanded }\end{array}$ & $\begin{array}{c}\text { ibraries with } \\
\text { Roles } \\
\text { Decreased }\end{array}$ & $\begin{array}{c}\text { ese Duties } \\
\text { Roles } \\
\text { Remained } \\
\text { The Same }\end{array}$ & Total & $\begin{array}{c}\text { Total } \\
\text { Response }\end{array}$ \\
\hline $\begin{array}{l}\text { Take the lead in/make major contribution to collect- } \\
\text { ing usage statistics }\end{array}$ & $55.3 \%(263)$ & $44.6 \%(95)$ & $6.6 \%(14)$ & $48.8 \%(104)$ & 213 & 476 \\
\hline Resolve complex copyright issues & $88.6 \%(418)$ & $35.2 \%(19)$ & $3.7 \%(2)$ & $61.1 \%(33)$ & 54 & 472 \\
\hline $\begin{array}{l}\text { Take the lead in/make major contribution to estab- } \\
\text { lishing/implementing library preservation plan }\end{array}$ & $78.8 \%(367)$ & $10.1 \%(26)$ & $11.1 \%(11)$ & $62.6 \%(62)$ & 99 & 466 \\
\hline $\begin{array}{l}\text { Create/implement the preservation plan for digital } \\
\text { resources }\end{array}$ & $85.7 \%(403)$ & $37.3 \%(25)$ & $9.0 \%(6)$ & $53.7 \%(36)$ & 67 & 470 \\
\hline $\begin{array}{l}\text { Establish priorities and procedures for the care and } \\
\text { maintenance of the research collection }\end{array}$ & $78.8 \%(369)$ & $21.2 \%(21)$ & $7.1 \%(7)$ & $71.7 \%(71)$ & 99 & 468 \\
\hline
\end{tabular}

Note: Respondents could choose multiple areas; therefore total responses exceed $N$. 